\title{
Microbial Degradation of Pesticide Residues and an Emphasis on the Degradation of Cypermethrin and 3-phenoxy Benzoic Acid: A Review
}

\author{
Yichen Huang ${ }^{1,+}$, Lijuan Xiao ${ }^{1,+}$, Feiyu Li ${ }^{1,+}$, Mengshi Xiao ${ }^{1,+}$, Derong Lin ${ }^{1,+, *}$, Xiaomei Long ${ }^{1}$ \\ and Zhijun $\mathrm{Wu}^{2}$ \\ 1 College of Food Science, Sichuan Agricultural University, Ya'an 625014, China; 18723091689@163.com (Y.H.); \\ 18728194686@163.com (L.X.); 18728190420@126.com (F.L.); 18227591863@163.com (M.X.); \\ 18428301943@126.com (X.L.) \\ 2 College of Mechanical and Electrical Engineering, Sichuan Agricultural University, Ya'an, 625014, China; \\ wzj@sicau.edu.cn \\ * Correspondence: lindr2018@sicau.edu.cn; Tel.: +86-835-288-2187 \\ + These authors contributed equally to this work.
}

Received: 26 July 2018; Accepted: 4 September 2018; Published: 11 September 2018

\begin{abstract}
Nowadays, pesticides are widely used in preventing and controlling the diseases and pests of crop, but at the same time pesticide residues have brought serious harm to human's health and the environment. It is an important subject to study microbial degradation of pesticides in soil environment in the field of internationally environmental restoration science and technology. This paper summarized the microbial species in the environment, the study of herbicide and pesticides degrading bacteria and the mechanism and application of pesticide microbial degrading bacteria. Cypermethrin and other pyrethroid pesticides were used widely currently, while they were difficult to be degraded in the natural conditions, and an intermediate metabolite, 3-phenoxy benzoic acid would be produced in the degradation process, causing the secondary pollution of agricultural products and a series of problems. Taking it above as an example, the paper paid attention to the degradation process of microorganism under natural conditions and factors affecting the microbial degradation of pesticide. In addition, the developed trend of the research on microbial degradation of pesticide and some obvious problems that need further solution were put forward.
\end{abstract}

Keywords: biodegradation; characteristic; degradation mechanism; degrading bacteria; pyrethroid

\section{Introduction}

From the end of the 20th century to the present, the total global grain output has increased from 500 million tons to 700 million tons now [1]. Among them, cereals account for $80 \%$ of human consumption of food [2]. Food is endangered by pests during its natural growth or storage. For example, China is a largely agricultural country, but 40 million tons which is about $8.8 \%$ of the country's total grain output are lost in vain because of a variety of insect pests every year [3]. India produces an average of 250 million tons of grain a year, but it also loses $11-15 \%$ of its total output, or about 27.5-37.5 million tons a year, due to pests and other causes [4]. To avoid such losses, pesticides are widely used to control agricultural and household pests [5]. The loss of food has been reduced a lot after the use of pesticides, but these pesticides are widely distributed in the soil, water, air, and agricultural products. So, the wide use of pesticides causes a great potential threat to the environment $[6,7]$. They not only pollute the soil and crops, but also further pollute the ground water as well as the marine environment, which directly threatens human's health and environment [8-13]. 
In order to solve the contradiction between agricultural products with high yield or stable production and environmental pollution, we can start from the following two aspects. On the one hand, pesticides with low toxicity, high efficiency and low pesticide residues should be found and developed, on the other hand, ways of degrading pesticide residues also should be fundamentally worthy of attention. Studies on microbial degradation of pesticide residues originated in 1940s, and as people pay more attention to the environment, the research on the degradation process and degradation mechanism of organic pollutants has been deeply studied. [14]. Bacteria in nature could degrade the pesticide residues, with low cost and environmentally friendly and it would not cause secondary pollution. But the efficiency was relatively slow and the natural environment was complex and changeable, which may affect the feasibility and efficiency of microbial degradation of pesticides. Consequently, researchers have conducted fine studies of bacteria and had a clear understanding of the degradation mechanism of organic pesticides. Among them, a number of bacteria that could degrade and convert pesticides have been isolated [15-17]. Besides, the mainly degradable ways and mechanisms of pesticides were described clearly [16,18-20]. According to the researches, the current studies of biodegradable pesticides that are mainly concentrated in the microorganism in the soil, such as fungi, bacteria, and actinomycetes [21], of which the main role are bacteria and fungi. Because the bacteria could easily induce mutant strains, which also had a variety of biochemical capacity to adaptive environment, and thus more in-depth study can be carried out [22-26].

The review can not only provide massive data and information for further study on the biodegradation of cypermethrin (CY) pesticides, in which were the detection method, model for screening microbes, degradation characteristics, and degradation pathway and mechanism, but also enriched and perfected the theory of biodegradation of CY pesticides. In addition, this review analyzed the degradation process of 3-PBA. The microbial degradation of CY and 3-PBA was studied, a new way for the breeding of degrading bacteria was provided, and the resources of degradable bacteria were enriched. Therefore, the review was of significant meaning and value to provide reference for other studies, such as biodegradation of other types of pesticides or veterinary drugs, using CY pesticides to biodegrade environmental pollution, eliminating or reducing pesticide residues in agricultural products.

\section{Research on the Progress of Microbial-Degradation of Pesticide Residues}

\subsection{The Main Types of Pesticides in Agriculture}

Organochlorine pesticides were very stable in the environment, and were easily enriched in the organisms' and human's body through the food, so China had forbidden producing and using them from 1983 onwards, such as hexachlorocyclohexane (666), 1,1,1-trichloro-2,2-bis(p-chlorophenyl) ethane (DDT) and other organochlorine pesticides $[27,28]$, in which like methamidophos in organic phosphorus were gradually phased out. Several types of organic pesticides were used in agriculture as shown in Table 1. 
Table 1. Kinds of pesticides used in agricultural production.

\begin{tabular}{|c|c|c|}
\hline & Types of Pesticides & Name of Pesticide \\
\hline \multirow{6}{*}{ Insecticide } & Organic nitrogen & Benzoylphenyl Ureas [29], chlordimeform [30]. \\
\hline & Organic phosphorus & $\begin{array}{l}\text { Acephate [31], azinphos-methyl [32], bromophos [32], } \\
\text { chlorpyrifos [31,32], coumaphos [33,34], diazinon [31-33], } \\
\text { dimethoate [18,31,33,34],dioxathion [34], disulfoton [32,33], } \\
\text { diazinon [32,33], ectophos [34], fenitrothion [31,32], fenitrooxon [32], } \\
\text { fonofos [32], glyphosate [32,33], leptophos [33], malathion [31-35], } \\
\text { mathamidophos [33], parathion [32], phenthoate [31,33], } \\
\text { profenofos [33], phorate [33], phosmet [36], phosphothion [34], } \\
\text { trichloffon [34], trichlorfon [33] }\end{array}$ \\
\hline & Organic chlorine & $\begin{array}{l}\text { Aldrin [18,32,35], chlordane [32,35,37], DDT [32,35], dieldrin [32,35], } \\
\text { dicofol [31], endosulfan [31,32,35], endrin [32], fipronil [31], } \\
\text { heptachlor, [32,35], lindane [35,38], } \gamma \text { - BHC [34], } \gamma \text { - } \\
\text { hexachlorocyclohexane [38] }\end{array}$ \\
\hline & Carbamate & $\begin{array}{l}\text { Aldicarb [39], carbaryl [31,34], carbofuran [31], carbosulfan, [31], } \\
\text { cartap [31] }\end{array}$ \\
\hline & Pyrethroid & $\begin{array}{l}\text { Cypermethrin [31], chlorfenvinphos [31], deltamethrin [31], } \\
\text { fenvalerate [29], flumethrin [31], permethrin [31], ivermectin [31] }\end{array}$ \\
\hline & Insect growth regulators & $\begin{array}{l}\text { Azadirachtin [40], benzoylphenylurea [40], diflubenzuron [40], } \\
\text { methoxyfenozide [40], pyriproxyfen [40], spinosad [40], } \\
\text { tebufenozide [40] }\end{array}$ \\
\hline Acaricides & \multicolumn{2}{|c|}{$\begin{array}{l}\text { Amitraz [41], coumaphos [21,41], dimethoatet [18], fenpyroximate [41], formic acid [41], menthol [41], } \\
\text { tau-fluvalinate [41], thymol [41] }\end{array}$} \\
\hline Herbicide & \multicolumn{2}{|c|}{$\begin{array}{l}\text { Acetanilides [42], alachlor [39], barban [35,43], chlorbromuron [35], hlorophenoxy [42], dalapon [35], } \\
\text { diuron [35,44], glyphosate [45], linuron [35,46], monuron [36], neburon [36], pendimethalin [36], } \\
\text { pentachlorophenol [36,47], propham [35], salted iron phosphorus [45], swep [35], 2,4-D [48], 2,4,5-T [35] }\end{array}$} \\
\hline Bactericide & \multicolumn{2}{|c|}{$\begin{array}{l}\text { Bayleton [48], blue copper [48], chlorothalonil [43], copper hydrochloride [48], copper oxychloride [48], } \\
\text { copper sulphate [48], different rice blast net [45], dithane [48], dithiocarbamates [42], mancozeb [48], } \\
\text { metalaxyl [45,49], methyl phosphorus [45], impact [45,48], polytrin [48], ridomil [48], rice blast net [45], } \\
\text { triazoles [42], thiocarbamates [42], thiovit [48] }\end{array}$} \\
\hline
\end{tabular}

In nature, there were a large number of microorganisms with strong adaptability and different types of metabolic. They could use a variety of synthetic organic matters like lucerne or horn meal, organophosphonates as carbon source, nitrogen source and energy. This would be conducive to their growth $[5,50,51]$, and also could completely mineralize or degrade the organic pesticide into small non-toxic molecules through various metabolism ways, and then ultimately achieved the purpose of purifying the environment [45].

\subsection{Types of Pesticides-Degrading Microorganism}

In recent years, many scientists have enriched, isolated, cultured and screened a lot of microbial floras, such as bacteria, fungi, actinomycetes, algae and other microbial strains from the natural sewage or soil to degrade pesticides. Kafilzadeh et al. [52] separated bacteria from sediments and water samples from high agricultural activity areas for the detection of endosulfan degradation. It was found that the five bacteria genus klebsiella, acinetobacter, alcaligenes, flavobacterium, and bacillus could degrade endosulfan effectively. Jayabarath et al. [53] selected 319 actinomycetes from saline soils of Sangli District (Maharashtra) for carbofuran tolerance test, while only the seven strains of Streptomyces alanosinicus, Streptoverticillium album, Nocardia farcinia, Streptomyces atratus, Nocardia vaccini, Nocardia amarae, and Micromonospora chalcea can grow and degrade pesticides very well. Elgueta et al. [54] used white-rot fungi to study the degradation of atrazine and found that the half-life of atrazine decreased to six days. Besides, Kabra et al. [55] studied the ability of green microalga Chlamydomonas mexicana to degrade atrazine and found that microalgae could effectively degrade atrazine by accumulating atrazine in cells and then degrading it, reaching a degradation rate of $14-36 \%$. Among them, the isolated bacteria were mainly Pseudomonas, Klebsiella pneumoniae, Bacillus subtilis, etc. Fungi included mycobacterium, Aspergillus, white rot fungi, etc. Algae included 
marine chlorella, etc. The common pesticide-degrading microorganisms were listed, as shown in Table 2.

Table 2. Commonly pesticide degrading microorganism.

\begin{tabular}{|c|c|c|}
\hline Types of Microorganism & Species & Example of Pesticide Degradation \\
\hline \multirow{3}{*}{ Bacteria } & Pseudomonas & $\begin{array}{l}\text { Aldrin [20], chlorpyrifos [20], coumaphos [33], ddt [20], } \\
\text { diazinon [20,33], endosulfan [20], endrin [20], } \\
\text { hexachlorocyclohexane [20], methyl parathion [20,33], } \\
\text { monocrotophos [20], parathion [20,33] }\end{array}$ \\
\hline & Bacillus & $\begin{array}{l}\text { Chlorpyrifos [20,33], coumaphos [33], DDT [20], diazinon [20], } \\
\text { dieldrin [20], endosulfan [20], endrin [20], glyphosate }[20,33] \text {, } \\
\text { methyl parathion }[20,33], \text { monocrotophos [20], } \\
\text { parathion }[20,33] \text {, polycyclic aromatic hydrocarbons [20] }\end{array}$ \\
\hline & $\begin{array}{c}\text { Alcaligenes } \\
\text { Flavobacterium }\end{array}$ & $\begin{array}{l}\text { Chlorpyrifos [20], endosulfan [20,52] } \\
\text { Diazinon [33], glyphosate [33], methyl parathion [33], } \\
\text { parathion [33] }\end{array}$ \\
\hline Actinomycetes & $\begin{array}{l}\text { Micromonospora, Actinomyces, } \\
\text { Nocardia, Streptomyces }\end{array}$ & $\begin{array}{l}\text { Aldrin [20], carbofuran [53], chlorpyrifos [20,56], } \\
\text { diazinon [56], diuron [44] }\end{array}$ \\
\hline Fungus & $\begin{array}{l}\text { White rot fungi, Rhizopus, Cladosporium, } \\
\text { Aspergillus fumigatus, Penicillium, } \\
\text { Aspergillus, Fusarium, Mucor, Trichoderma } \\
\text { spp, Mortierella sp. }\end{array}$ & $\begin{array}{l}\text { Alachlor [39], aldicarb [39], atrazine [39,54], carbofuran [35], } \\
\text { chlordane [35], chlorpyrifos [33], DDT [35], diuron [57], } \\
\text { endosulfan [32,58-60], esfenvalerate [61], fenitrothion [62], } \\
\text { fenitrooxon [62], fipronil [63], heptachlor epoxide [64], } \\
\text { lindane [35,38], malathion [35] metalaxyl [49], } \\
\text { pentachlorophenol [35], terbuthylazine [57], 2,4-D [35] }\end{array}$ \\
\hline Algae & $\begin{array}{l}\text { Small green algae } \\
\text { Chlamydomonas } \\
\text { Genus of diatoms }\end{array}$ & $\begin{array}{l}\text { Phorate [45], parathion [45] } \\
\text { Atrazine [55], fenvalerate [65] } \\
\text { DDT [66], patoran [66] }\end{array}$ \\
\hline
\end{tabular}

Description: Bacteria has strong adaptability and is easy to induce mutations and occupies the main position in the study of degradation of pesticide. In addition to the above, there are a lot of pesticide degrading bacteria, such as Escherichia coli, Clostridium, Escherichia coli, Bacillus licheniformis, Thiobacillus and so on.

\subsection{Mechanism of Microbial Degradation of Pesticides}

Pesticides in the soil could be degraded by different ways; the traditional methods included physical degradation, chemical degradation, and physical-chemical degradation, which basically caused secondary pollution [67-69]. In recent years, microbial degradation was used more frequently because pesticides were used as mainly microbial nutrient, and ultimately decomposed into some small molecules, such as $\mathrm{CO}_{2}$ and $\mathrm{H}_{2} \mathrm{O}$. The progress was called enzymatic reaction, which included that the compound got into microorganism' body through a certain way firstly, and then through a series of physiological and biochemical reactions under the action of various enzymes, finally pesticide would be completely degraded or broken down into smaller molecular compounds which have non-toxicity or less toxicity [45,70]. For example, Pseudomonas sp strain ADP used atrazine as the only carbon source, and three enzymes were involved in the first few steps of degradation of atrazine. The first enzyme was AtzA, which catalyzed the reaction of hydrolysis dechlorination of atrazine to non-toxic hydroxyl atrazine, and it was a key enzyme of atrazine's biological degradation. The second enzyme was AtzB, which catalyzed the dehydrochlorination of the hydroxy atrazine to produce $\mathrm{N}$-isopropyl cyanuric amide. The third enzyme was AtzC, which catalyzed the cyanuric acid and isopropylamine formated by $\mathrm{N}$-isopropyl cyanuric amide. Finally, atrazine was degraded to $\mathrm{CO}_{2}$ and $\mathrm{NH}_{3}[71,72]$. As degrading enzymes were often more resistant to abnormally environmental conditions than microbial cells that could produce such enzymes, and the degradable efficiency of enzymes was much higher than that of microorganism, especially for low concentrations of pesticides. Therefore, that people wanted to utilize degrading enzymes to purify the environment, which was polluted by pesticides would be a more effective way. However, the degrading enzyme was easily inactivated under the effect of non-degeneration and soil adsorption in the soil, so it was difficult to maintain the degradable activity for a long time. Also, the poor mobility of the enzyme in the soil and other factors limited the application of degrading enzymes in practice [22,23]. Many trials have been demonstrated that most of the genes encoding these enzymes were controlled on the plasmid $[9,46,73]$, for example, 
the bio-degradation of 2,4-D was controlled by the gene carried on the plasmid [74]. Pesticides were degraded through the expression of plasmid gene and chromosome gene in the bacteria.

The degradable ways included oxidation (hydroxylation reactions, such as aromatic hydroxylation, aliphatic hydroxylation, N-hydroxylation, epoxidation, N-oxidation, P-oxidation, S-oxidation, oxidative dealkylation, oxidative dehalogenation, and oxidative deamination), reduction (reduction of nitro group, quinone reduction, and reductive dehalogenation), hydrolysis (some esters such as thiophosphate, thiocarbamate, etc., which have ester bonds that can be hydrolyzed by bacteria), dehydrogenation, dehalogenation, decarboxylation, condensation, synthesis and so on $[35,42]$. The bacteria would convert organic macromolecules into small non-toxic molecules, thus avoiding the secondary pollution. Studies have shown that mineralization and co-metabolism were the main mechanisms for the further degradation of pesticides and their intermediate products [18,75-77].

The whole degradation mechanism was divided into three parts. Firstly, adsorption of target, it took place on the surface of the cell membrane and was a dynamic equilibrium process that was also critical. Secondly, the target got into the cell through the surface of the cell membrane, and the penetrated rate and efficiency were related to the molecular structure of the target isomerism. Thirdly, xenobiotic target conducted rapidly enzymatic reaction in the membrane [78].

Mineralization was a general term for the conversion of organic compounds into inorganic compounds under the action of soil microbes. Many chemical pesticides were analogs of natural compounds, and some microorganism had the enzymes to degrade them. They could be used as a source of microbial nutrients and then be degraded to inorganic matters, carbon dioxide, and water by microorganism. Mineralization was an ideal way to degrade because pesticides were completely degraded into non-toxic inorganic substance. Co-metabolic referred to that some chemical substances like insecticides, fungicides, and herbicides, etc. which did not exist in natural conditions, could be degraded not by bacteria or fungi easily, but only by adding some organic matter such as exogenous or iso-biomass as the primary energy [79]. Taking a type of co-metabolism as an example, the degradation products of the monomethylamine products of Pseudomonas dendrolimus DR-8 were 2,4-dimethylaniline and NH3, whereas the DR-8 strain could grow with other organic nutrient substrates added as carbon source and energy source instead of meth amidine, meanwhile the degradable products were not completely mineralized [80]. Co-metabolism played a major role in the microbial degradation of pesticides. It should be noted that in most cases, the synergistic effect of a series of reactions rather than a single reaction was needed to complete the degradable process of pesticides in the microbial body. For example, Deng et al. found that Aspergillus niger YAT could degrade beta-CY $(\beta-C Y)$ and its intermediates completely by co-metabolism and mineralization way, and the whole degradable process was analyzed, while there was rare analysis in other pyrethroid degrading strains. The degradable pathway of $\beta$-CY by Aspergillus niger YAT could be seen in Figure 1 [81]. 


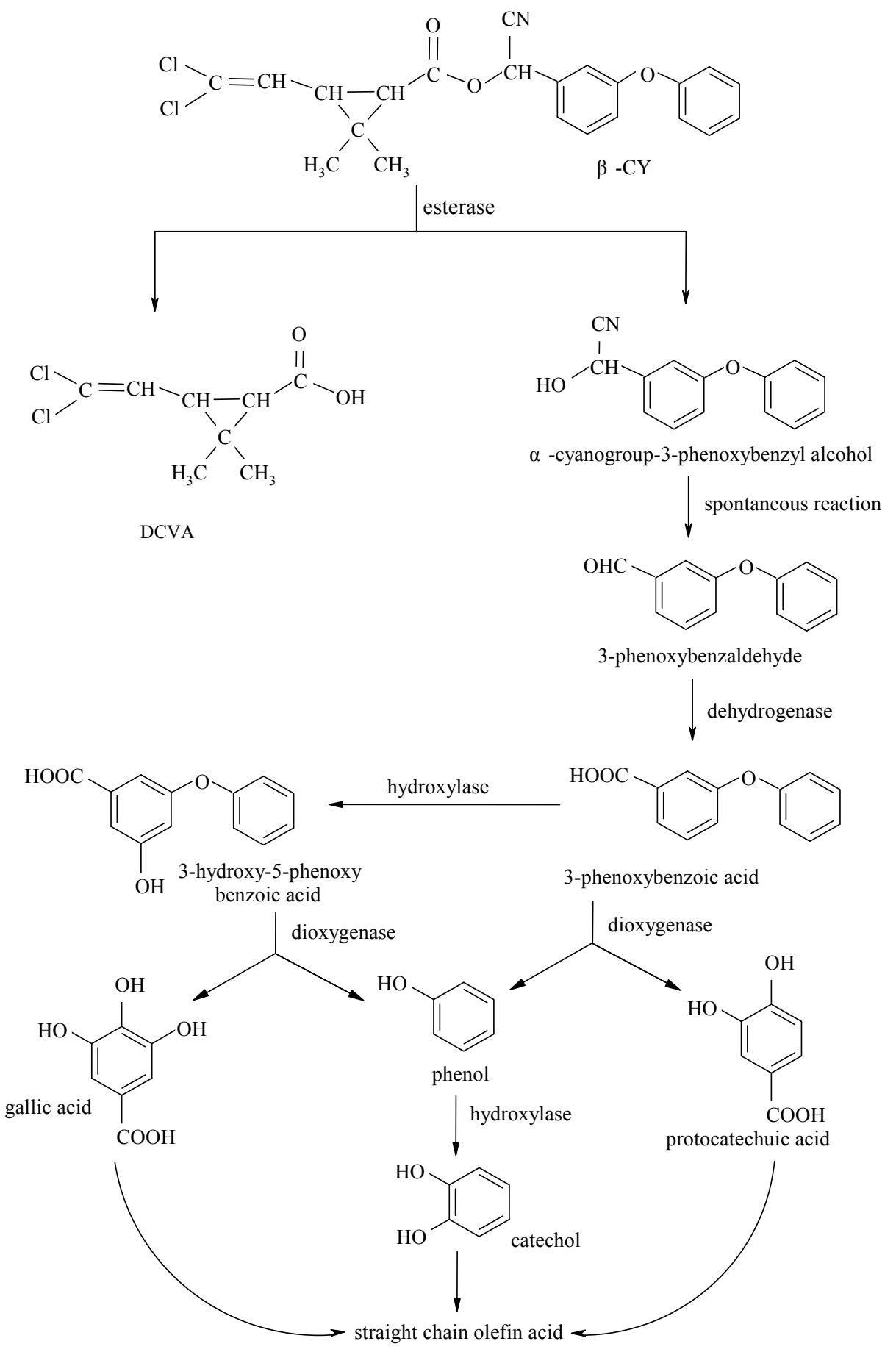

Figure 1. Degradation pathway of beta-CY ( $\beta-C Y)$ by Aspergillus niger YAT (Taken from Deng et al. 2015).

\subsection{Factors Affecting Microbial Degradation of Pesticide Residues}

Microbial degradation of pesticide residues was restricted by many factors which was divided into internal factors and external environmental factors, in which the effect of internal factors originated from the structure of pesticide and the micro-organisms.

(1) Degradation and transformation of pesticides was affected by microbial species, metabolic activity, and adaptability directly [82].

Many experiments have shown that the reactions of different species of microorganism or the same species of different strains to the same organic substrate or toxic metal were different, and the 
microorganism had a strong ability to adapt environment and to be domesticated. Through the adapted process, the new compounds could induce microorganism to produce the corresponding enzyme system or establish a new enzyme system to degrade them. Functional characteristics and changes of degradation were the most important factors [83-86].

(2) Effect of pesticide structure

Pesticides' own factors, such as their molecular weight, spatial structure, the number and type of substituents, substituted characteristics and location affected the rate and efficiency of microbial degradation of pesticides [87-89]. In general, the polymer compound was less biodegradable than the low molecular weight compound. The polymer and composite were more resistant to bio-degradation, but that with simpler space structure was degraded more easily [90]. Microbial degradation of rhizosphere was the main route of phytoremediation on soil contaminated by polycyclic aromatic hydrocarbons (PAHs). Plant absorption was a relatively minor pathway, and mixed planting could improve the efficiency of these two ways simultaneously. For different kinds of PAHs, plants were easier to absorb 2-4 ring PAHs.

The use of herbicides has become an indispensable means of agricultural production, and thus many problems of environmental pollution have become increasingly prominent, such as the threat to the living environment and excessive pesticide content of agricultural and sideline products. Then, contaminated agricultural products got into human's body and harm human's health by the bio-accumulation of food chain and so on. Most of the current contaminants were synthesized biological heterologous organic substances which did not exist in nature, they often showed a strong resistance on the degradation of microorganism. It may be explained that the time of these compounds' getting into the nature was relatively short so that single microorganism has not evolved the metabolic mechanisms about degradation of such compounds. Although some dangerous compounds may be degraded slowly in nature through the mineralization and co-metabolism by natural formed microbial populations, this was still a new challenge for the microbial world. The process of microbial degradation was very slow, and it may need to change some structure. When comparing with the currently widely used synthetic bio heterologous substances, the natural evolutionary process of microorganism was clearly unable to meet the requirements of microbial pesticides' degradation, as the speed of the process was far from reaching what the environment and human needed. Thus, the balance of the entire ecosystem would be destroyed after a long-term effect [18]. Therefore, it was very important and urgent to study some of the methods that can make microbial flora achieve maximum degradation of pesticide in a relatively short time.

\section{(3) Environmental factors}

Temperature, humidity, salinity, $\mathrm{pH}$, nutrition, carbon dioxide, oxygen, substrate concentration, surfactant, etc. would affect the degradation [91-94]. Bacteria or their enzymes needed a suitable temperature, $\mathrm{pH}$ and substrate concentration [95]. The number of benzene rings of PAHs had a great impact on the microbial degradation of PAHs. The degradation of two rings and tricyclic compounds (naphthalene, phenanthrene, anthracene, fluorene, etc.), which existed in the environment only need a short time, and microorganism can mineralize these compounds with using PAHs as the sole carbon source. However, the four-ring and other multi-ring PAHs with high molecular weight were stable in the environment so that they were difficult to be degraded. But, the white rot fungi could degrade these compounds by metabolism [96]. Generally, with the increase of the number of benzene rings of PAHs, octanol/water partition coefficient increased, and the degradable rate was lower and lower. Surfactant could change the solubility of PAHs in soils, the balance of adsorption and desorption, and the interaction between PAHs and soil microorganism, thus further chang the bioavailability of PAHs. For example, Yuan et al. used the way of reducing the interfacial tension between soil and water to increase the solubility of PAHs, facilitate the transport of PAHs, and thus the bioavailability of PAHs increased. However, due to the toxic effects of surfactants on microorganism or the use of non-toxic 
surfactants as microbial growth matrix, the bioavailability of PAHs might be inhibited. In addition, the effect of surfactants on the bioavailability of different forms of PAHs in soils was different, so that the surfactant could be added to increase the solubility of PAHs in the aqueous phase, promote solid phase transferring to the water phase, improve bioavailability, and reduce the surface and interfacial tension of matrix [97].

The lack of nutrients was an important limiting factor for microbial growth and maintenance of population. Lewis and other studies have shown that maintaining the normal ratio of C:N:P in the polluted environment can promote the degradation of PAHs stably. In order to have a complete degradation and to speed up the purification rate, ammonia and phosphate were often added to adjust the C: N: P ratio in bio-repair.

Temperature and humidity were the most important factors, which affected the growth and reproduction of bacteria [98]. Zhu et al. investigated that the degradation and mineralization of biaryl compounds in soil and compost by bacteria Ralstonia and Pickettii, and found that the nonionic surfactants tween 80 can enhance bacteria's utilization of biaryl compounds under suitable soil moisture conditions, such as biphenyl, 4-chlorobipheny [99,100]. Gupta et al. thought that the effect of organic substrate content on pesticide's degradation in composting was greater than that of bacteria content when compost was mixed with soil contaminated by PAHs. Because bacteria did not produce energy and need other carbon and energy source, so nutrition was more important when bacteria degraded pesticides by co-metabolism [101,102].

At present, pesticides in agriculture were mainly including organic phosphorus, organic chlorine, carbamate, pyrethroid, chloronicotinyl insecticide and some other fungicide, etc. Many microorganisms that degraded pesticides could be screened from natural sewage or soil, which included bacteria, fungi, actinomycetes, algae, and other microbial strains. Bacteria were Pseudomonas, Klebsiella sp., Bacillus subtilis, etc. Fungi were Trichoderma spp., Aspergillus spp., white rot fungi, etc. Algae had marine chlorella, and so on. In addition to the traditional methods, such as physical degradation method, chemical degradation method, and so on, the microbial degradation method was commonly used in pesticide degradation. This method had high efficiency, low cost, and good degradation effect. Microorganism used some substances in pesticides as nutrients and decompose them into small molecules, and the main ways of degradation were mineralization and co-metabolism. The effects of degradation were influenced by many factors, such as the type of pesticide, the type of microorganism, and temperature, humidity, acidity, and air's composition in the environment. The purpose of these studies was to screen the most suitable microorganism for different pesticides, the most suitable degradation methods and degradation environment, which provided a more convenient reference for future research.

\section{Present Situation of Degrading Pesticides by Micro-Organisms}

At present, there were many researches that were devoted to microbial degradation of pesticides [37,103-105]. For example, there was a type of biological technology named the immobilized bacteria technology rising in the just 1980s, namely using free cells or enzymes fixed in the limited space, and keeping them active meanwhile, which also can be reused [106-108]. This technology was characterized by efficient use of two strains with low pollution.

Construction of the system of several bacteria allowed for several bacteria to solve the problem of the incomplete transformation of single strain [24,25]. A study discussed the microbial cell's surface display technology that developed in the middle of 1980s $[109,110]$, which showed a process about the combination of exogenous protein (this protein has enzyme activity) with degradable strain, this procedure was active and it could combine the function of transport and secretory so as to make the exogenous protein express better. Finally, the exogenous protein was embedded in the surface of cell membrane and played the specific function of the customary exogenous proteins. This method created a direct contact between the bacteria and the pesticide residues, which not only simplified the purification process of proteins, but also improved the degradable rate [111,112]. 
In addition, in 1994, American scientist Stemmer et al. introduced the advanced technology of simulated DNA shuffling in vitro contained in Darwinian theory. The reorganization technology made the activity of enzymes greatly improved, and it did not require the three-dimensional structure determination of enzyme [113]. People have done a lot of researches on the degradable plasmid of the herbicide 2,4-D and 2,4,5-T, and these studies proved that the main 2,4-D-degrading bacteria were Peseudomonas sp. and Alicaligenes sp. which contained the plasmid of pjP4 Alicaligenes eutophus JMP134d [22,23,97].

Ma et al. [114] used Southern hybridization and plasmid curing to get the fact that the naphthalene dioxygenase (ndo) gene of PAH degrading bacteria Pseudomonas sp. would be immobilized on a large self-transmissible plasmid and then transferred to thermophilic strains, and similar temperature optim was also observed. The study on plasmid all over the world in the separation and screening of degrading bacteria strains were of great deal, but there was very few on the degradable bacteria. Most of them were applied degrading bacteria directly in the pot experiment.

The results of a number of researches showed that the degrading bacteria isolated from both pot experiment and field experiment had good degradation, and the degradable rate even achieved more than $70 \%$. The degradable rate of most strains was more than $90 \%$, which greatly shortened the half-life.

Some studies have shown that certain enzyme could endure the variation of environmental conditions while the bacteria which produced this enzyme could not. For example, Parathion Hydrolase could tolerate salt's concentration as high as $10 \%, 1 \%$ of the solvent concentration and $50{ }^{\circ} \mathrm{C}$ of the temperature, but Pseudomonas which could produce this enzyme in this condition cannot grow. The immobilized enzyme not only had the good purified effect of CY, but also degraded organophosphorus and pyrethroid pesticides.

Microbial degradation of pesticide pollution by using composite systems with a variety of microbial taxa was an inevitable trend, which was close coordination between the composite nature of bacteria and comply with the laws of nature. The artificially composite systems of micro-organisms were inoculated to pesticide pollution in soil or to improve the utilization of agriculturally organic waste composting have been a good way to deal with polluted soil. The modern city life's garbage, organic solid waste, sewage sludge contains large amounts of organic pollutants and heavy metals, and agriculturally organic solid wastes all contained a large number of pesticide residues and other pollutants. In the process of composting, the pollutants were eliminated by microbial degradation and volatilization, leaching, photolysis, chelation, complexation, and so on [115]. At the same time, the microbial system was compositely contained in the active compost, and it was more likely to become the dominant flora of polluted soils. Therefore, the composting method could not only eliminate pollution, but also get high quality compost products, which had great significance on sustainable development for environmental pollution control and agricultural major.

The author deemed that the construction of cooperative relations between strains could not only improve the efficiency of lignocellulose decomposition composite system, but also improve the long-term stability of constituent species, and it was not easy to be contaminated $[14,116]$. On this basis, the complex system gave the function of pesticide decomposition, which had a strong ability to decompose a variety of pesticides and it had a well applicable effect.

In short, although the microbial degradation of pesticide residues had made initial progress and most kinds of microbial strains to degrade pesticide had been identified, the practical application of microbial bioremediation was often affected due to the degradation efficiency was low. So, the microbial degradation of pesticide residues was still a problem that needed to be overcome. 


\section{Microbial Degradation of CY and its Application}

\subsection{Overview of $C Y$}

Pyrethroid insecticides were synthetic pesticides used to kill warms that were based on natural pyrethrum structure. At present, the amount of pyrethroid, organophosphate, and carbamate was accounting for about $20 \%$ of the world market [117]. The acute toxicity of pyrethroid pesticides was smaller and the doses were lower. In the past, the pyrethroids have been considered to be degraded by oxidase system in vivo and it does not have accumulation. In other words, these pesticides were safe so they get wide use, and the amount of pesticides has been increasing gradually in the production of fruits and vegetables. However, the recent studies have shown that these pesticides had accumulated in animal and plant bodies, and they may cause chronic disease in long-term exposure [118]. Some types of pyrethroid pesticides had carcinogenic, teratogenic, and mutagenic effect [119]. In a way, the pesticides were provided with moderate neurotoxic effects, immune system, cardiovascular toxicity and genetic toxicity on mammalian toxicity and there was no specific drug to treat the toxicity [120]. Therefore, all the countries in the world had made a limited standard for pyrethroid pesticide residues in the products, and the excessive pesticide residues was one of the most important obstacles to export agricultural products.

\subsection{The Structure and Overview of $\mathrm{CY}$}

CY was a commonly used pyrethroid pesticides, molecular formula $\mathrm{C}_{22} \mathrm{H}_{19} \mathrm{C}_{12} \mathrm{NO}_{3}$, molecular weight of 416.32. There were some functional groups in the $\mathrm{CY}$ molecule, such as ester bond, halogen double bond, cyanide bond, and benzyl carbon. There were three asymmetric carbon atoms, one was combined with cyano group, and the others were the first and the third carbon atoms of the cyclopropane carboxylic acid. Therefore, $\mathrm{CY}$ had four raceme and eight isomers, and CY was in the same side of the hydrogen atom with the first position of the alkyl group and the carbon atom of the third order, which was known as cis isomers, and in the opposite side was called trans isomer [121].

$\mathrm{CY}$ was one of the most commonly used pyrethroid pesticides and accounting for about $50 \%$ in the CY pesticide market [122]. The pesticides were produced in 1975 by the British Mitchell Cotts, ICI, FMC, Swiss Ciba-Geigy, Japan Sumitomo, and Dutch Shell, which could be used for the treatment of tea, vegetables, fruit trees, cotton flowers and trees, and the prevention and control of pests and parasitic disease. Otherwise, pesticides characteristics were seized to make the environment stable, slow the process of degradation, and reduce the degradable rate [123].

There were obvious differences between different isomers of $\mathrm{CY}$ in insecticidal effect and photolysis rate, the insecticidal activity from strong to weak was cis-, trans- and cis trans-CY [121], insecticidal activity of the ester was highest, which was made of the ring structure of the acid and $S$ configuration of alcohol.

It played an important role in the prevention of pests in crop. With a number of highly toxic organophosphorus pesticides banned, the scope of application of CY was more and more widely, and its usage was increasing. But $C Y$ was not easy to be degraded by air and light, which made its half-life in the natural environment up to 94-1103 days.

\subsection{Study on Degradation of CY at Home and Abroad}

At present, the degrading bacteria for $\mathrm{CY}$ degradation on the domestic and foreign were Micrococcus sp., Serratia sp, Klebsiella sp., Bacillusu sp., Rhodococcus sp., KlebMella sp., seudom onasaeruginosa, Aspergillus terreua, Monilochaetes and Fusarium, Alcaligenes sp., and so on. Deng et al. studied the kinetic parameters of the degradation of $\beta$-CY by YAT under the effects of different factors, and the results were shown on Table 3. With the substrate concentrations of $25-100 \mathrm{mg} / \mathrm{L}$, the half-life of $\beta-\mathrm{CY}$ was rather varied and enlarged with the increase of substrate concentrations. The particular strain could degrade $\beta-\mathrm{CY}$ validly over a range of temperatures $\left(25-35^{\circ} \mathrm{C}\right)$ and $\mathrm{pH}(6.0-8.0)$, which made pesticide-degrading bacteria had advantages in the 
environment. Except that, they also discussed the growth's characteristics and the degradable capacity of $\beta$-CY for Aspergillus niger YAT (Figure 2). The results showed that $\beta-C Y$ made no difference in the growth of YAT in PD, it prolonged YAT's lag phase, but it did not affect its final amount of growth. Accompanying with rapid growth of YAT after $24 \mathrm{~h}, \beta-\mathrm{CY}$ was degraded rapidly, degradable rate reached $41.32 \%$ at $120 \mathrm{~h}$. Then strains basically did not grow, and the degradable rate reached $54.83 \%$ at $168 \mathrm{~h}$ [81]. Deng et al. [81] received Bacillus licheniformis that were isolated from enriched culture in the activated sludge, and used 10\% CY with EC to spray vegetables. After one day, there were some experiments on the field sprayed degrading bacteria, and then after every five days collected sample. The results of gas chromatography analysis were that the bacteria could effectively remove CY residues in vegetable's surface, and within five days of the removing rate was $64 \%$. In the experiment, the degradable rate of CY in tea was up to $68.94 \%$. Enterobacter cloacap, which was screened from the sludge in the sewer of pesticide's factory, was dealt with $100 \mathrm{mg} \cdot \mathrm{L}^{-1} \mathrm{CY} 3 \mathrm{D}$ and the medium was fermented broth based on the environment of $30{ }^{\circ} \mathrm{C}$ and the $\mathrm{pH}$ of 7.0. At last, the degradable rate of CY was over $50 \%$ [124].

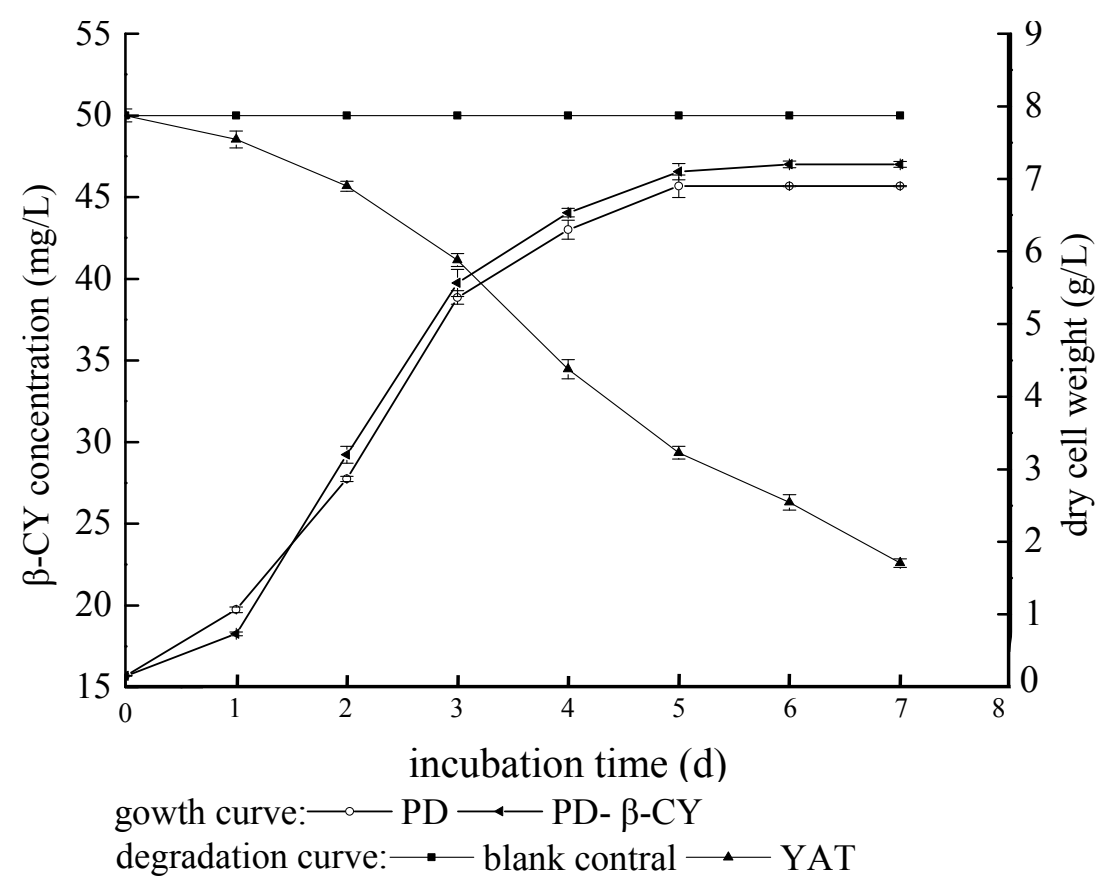

Figure 2. Growth characteristics and $\beta-\mathrm{CY}$ degradation curves of Aspergillus niger YAT (Taken from Deng et al. 2015).

From the farm soil and the mixed soil composed of various soil samples, Serratia sp. and Pseudomonas aeruginosa were isolated, which could degrade CY at least 50\% in 20 days [125]. Fusarium isolated from soil was cultured for eight days under the conditions of $28^{\circ} \mathrm{C}$ in the rotary table, and then incubated for five to seven days in 26-30 ${ }^{\circ} \mathrm{C}$. By high-performance liquid chromatography (HPLC) analysis of CY in $4^{\circ} \mathrm{C}, 60-80 \%$ of the $100 \mathrm{mg} / \mathrm{L} \mathrm{CY}$ could be degraded in 5 days [126]. By enrichment incubation, bacillus subtilis separated from the sludge were used to degrade betacypermethrin [127]. The efficiency of some bacteria to degrade CY was constrained by environmental minerals, carbon sources, water and so on [125]. At present, the reports on microbial degradation of CY were relatively small, so was the research on the CY degrading strains. There were some studies the characteristics of CY-degrading Strain. Chen et al. [70,128] isolated a strain of degrading bacterium streptomyces sp. HP-S-01 from the chemical plant waste-water treatment pool of long-term production of pyrethroid pesticides, and the streptomyces could completely degrade CY by using Andrews equation of streptomyces HP-S-01 to analyze the dynamic process of degrading CY, besides, further physiological characteristics of degrading bacteria was studied. First, there was a relative 
curve of Streptomyces HP-S-01 growth and the degradation of CY in the result. It can be seen from the Figure 2, CY's degradation and cell growth were positively correlated with the existence of CY. In the presence of CY, streptomyces' growth had no obvious retention period, and it quickly entered the logarithmic growth phase, and logarithmic growth phase of streptomyces was one to two days. In the process, the degradation to $\beta-\mathrm{CY}$ in the Streptomyces was the fastest. Second, there was the influence of bacterial count on streptococcus HP-S-01 to degrade CY. When the amount of inoculation in streptomyces was $0.2-0.6 \mathrm{~g} / \mathrm{L}$, the degradable rate showed an upward trend in total. From that, the visibly degradable ability of streptomyces can improve in a certain range with the increase of the amount of inoculation. When the inoculated amount was up to $0.6 \mathrm{~g} / \mathrm{L}$, the degradable rate rose rapidly, then the concentration had the greatest influences on the degradation of CY. But, when the inoculated amount was higher, there was no effect. Third, there was the effect of temperature on streptomyces HP-S-01 to degrade CY. Obviously, the best degradable temperature was $28{ }^{\circ} \mathrm{C}$, higher than the temperature or below this temperature, the degradable effect would be inhibited, and the degradable rate would decrease. Especially in $18{ }^{\circ} \mathrm{C}$ and $38^{\circ} \mathrm{C}$, the degradable ability was the lowest. Finally, $\mathrm{pH}$ affected the degradation of $\mathrm{CY}$ by streptomyces sp. HP-S-01. When $\mathrm{pH}<7.5$, the streptomyces' degradation of $\beta-\mathrm{CY}$ ratio increased with the increase of $\mathrm{pH}$, when $\mathrm{pH}>7.5$, streptomyces' degradation of $\beta-\mathrm{CY}$ decreased with the increase of $\mathrm{pH}$, which indicated that the most suitable $\mathrm{pH}$ was 7.5. It also showed that the bacteria had better degradable ability under partial alkaline conditions.

Table 3. Kinetic parameters of degradation of $\beta-C Y$ by YAT under the effects of different factors (Taken from Deng et al. 2015).

\begin{tabular}{|c|c|c|c|c|c|}
\hline \multicolumn{2}{|l|}{ Factors } & Kinetic Equation & $T_{1 / 2}$ (Day) & $K_{d}\left(m g /\left(L \cdot\right.\right.$ day $\left.^{-1}\right)$ & $\mathbf{R}^{2}$ \\
\hline \multirow{4}{*}{$\mathrm{C}_{0}(\mathrm{mg} / \mathrm{L})$} & 25 & $C_{t}=25.78 e^{-0.194 t}$ & 3.573 & 0.194 & 0.924 \\
\hline & 50 & $C_{t}=50.14 e^{-0.110 t}$ & 6.301 & 0.110 & 0.921 \\
\hline & 100 & $C_{t}=100.81 e^{-0.059 t}$ & 11.748 & 0.059 & 0.950 \\
\hline & 25 & $C_{t}=50.25 e^{-0.103 t}$ & 6.730 & 0.103 & 0.945 \\
\hline \multirow[t]{3}{*}{ Temperature $\left({ }^{\circ} \mathrm{C}\right)$} & 30 & $C_{t}=50.14 e^{-0.110 t}$ & 6.301 & 0.110 & 0.921 \\
\hline & 35 & $C_{t}=50.21 e^{-0.118 t}$ & 5.874 & 0.118 & 0.990 \\
\hline & 6.0 & $C_{t}=50.37 \mathrm{e}^{-0.094 t}$ & 7.374 & 0.094 & 0.910 \\
\hline \multirow[t]{2}{*}{$\mathrm{pH}$} & 7.0 & $C_{t}=50.14 e^{-0.110 t}$ & 6.301 & 0.110 & 0.921 \\
\hline & 8.0 & $C_{t}=50.09 e^{-0.120 t}$ & 5.776 & 0.120 & 0.915 \\
\hline
\end{tabular}

Singh [5] compared the Chabishi medium, potato dextrose agar, Richard medium, oatmeal medium and corn powder liquid medium to study the effect of five kinds of medium on $C Y$ degrading strain Fusarium sp. HG-P-01 growth, and the result showed that the Chabishi medium was the most suitable medium for mycelial growth. Through this experiment, the optimum concentration of formula, carbon nitrogen, and phosphorus and the expected degradable rate were established. There was a sample of CY HPLC chromatogram. CY standard sample's peak was composed of two peaks, and the peaks were sharp, symmetry, stable, and the reserved time were $3.643 \mathrm{~min}$ and $3.840 \mathrm{~min}$. The standard curve equation was $Y=51.309 X+10.932$, and the correlated coefficient was $R^{2}=0.9999$. The concentration of reagent was significantly relative with corresponding peak area, so the results were reliable. Tallur et al. [129] studied the synergistic effect of mixed microbial to degrade CY by field's tests, and determined the effects of different temperatures, different spraying time, different degradable bacteria concentration, and different days on the degradable rate of CY. In the result, the optimum water bath temperature was $33^{\circ} \mathrm{C}$, the spraying time was $5 \mathrm{pm}$., the concentration of cell was $\mathrm{OD}_{600}$ 1.0. Zhang et al. [79] isolated and screened two strains of Serratia spp. strain JC1 and JCN13 from activated sludge, and then studied the degradable ability to the CY and the cell's surface hydrophobicity. The results showed that JCN13 has higher hydrophobicity and degradation ability than JC1, which mean that the high hydrophobicity of the cell of degrading bacteria can enhance the degradation of CY. There was a comparison of cell's surface hydrophobicity of strain L12 in xylene and n-octanol [79]. The hydrophobicity of bacterial cell's surface was one of the most 
important determinants of nonspecific bacterial adhesion of bacteria to variously biological and abiotic surfaces and interfaces, and it was also one of the main elements that affected bacterial uptake and the degradation of hydrophobic organic matter [93]. It had important significance of studying the cell's surface hydrophobicity to degrade organic compounds in non-aqueous phase.

\section{Microbial Degradation of 3-phenoxy Benzoic Acid (3-PBA) and its Application}

\subsection{Structure and Properties of 3-PBA}

3-PBA was white powder crystal, molecular formula $\mathrm{C}_{13} \mathrm{H}_{10} \mathrm{O}_{3}$, molecular weight is 214.2 , and the melting point of $149-150{ }^{\circ} \mathrm{C}$. It was difficult to dissolve in water $\left(20^{\circ} \mathrm{C}\right.$ water solubility is $\left.200 \mathrm{mg} / \mathrm{L}\right)$ and is easy to dissolve in organic solvents. 3-PBA was one of the degradable products of most CY pesticides [130]. Some researchers showed specific esterase produced by bacteria acted on the ester bond in the molecule of CY pesticides. In the case of CY, it became two intermediates contained lnulin component and cyanalcohol [130-132]. Alpha $\alpha$-cyano-3-benzyl alcohol produced in the process that could be further oxidized to 3-PBA $[130,131]$. Deng et al. found that the metabolites of the process of $\beta-C Y$ degradation was 3-PBA by using the method of HPLC chromatogram, that was to say that the $\beta-C Y$ could be degraded to 3-PBA. After that, the metabolites of 3-PBA's degradation by strain YAT was further studied [133].

\subsection{Current Problems of 3-PBA}

3-PBA was one of the most degradable intermediates to pyrethroid pesticides, and had certain estrogenic properties, the faster migrated rate, longer half-life and stronger reproductive toxicity [113,134-138]. When comparing with pyrethroid pesticide, its hydrophobicity was relatively weak, and it was easier to migrate and accumulate in the environment. More and more 3-PBA remained in the soil, agricultural, livestock products, and even the body, did harm to the ecological environment and human's health and had more hazard potential effect than pyrethroids because its antibacterial activity restricted the bio-degradation of $\beta$-CY [130]. 3-PBA produced secondary pollution in the environment and agriculture, at the same time, it also blocked the pyrethroid pesticide's degradation into small non-toxic molecules [139], making the pesticide's residue become more serious. Therefore, the degradation of 3-PBA was the key to the elimination of pyrethroid pesticide pollution [140]. How to reduce and eliminate the pollution of 3-PBA in the environment and agricultural products had received extensive attention $[139,140]$, but the utilization of biodegradable enzyme was thought to be the effective way to reduce or eliminate the pesticide residues in agricultural products and control the environmental pollution by pesticide $[134,135,137]$. At present, it was reported that active sludge and soil were the main screening sources of 3-PBA degrading bacteria [78,132,136].

\subsection{Degrading Bacteria of 3-PBA and Simultaneous Degradation of 3-PBA and CY}

At present, the degrading microbes of 3-PBA were mainly Pseudomonas, fungi and actinomycetes were relatively few, and at this stage, studies of bio-degradation of 3-PBA remained at the screening and degrading bacteria [141]. The strains have been proved to be the following strains, for example, Sphingomonas sp.SC-1 from the active sludge [133], Aspergillus niger YAT1 in brick tea, the Eurotium cristatum ET1 in Fuzhuan tea [113], Aspergillus oryzae M-4, Sphingomon As sp.JZ-2, and Micrococus sp. CPN1 in soy sauce koji [142], etc. SC-1 could completely degrade 300ug/mL in one day, which was currently reported to be able to degrade 3-PBA and as the sole source of carbon mineralization to degrade it [133]. On the other hand, Deng et al. obtained a set of data by using HPLC-UV method to screen degrading bacteria of $\beta-C Y$ and 3-PBA, which could be seen in Table 4 [81]. Synergy was an important way to degrade pesticide's residues by bacteria. What has already been mentioned above could improve the degradable rate of pyrethroid pesticides, but few reported to degrade $\beta$-CY and 3-PBA on the same time. Dg-s-01 could endure and degrade high concentration of 3-PBA (100 mg/L) and degrade $\beta-C Y$ by using sphingobium at the same time [81]. Deng et al. established a HPLC 
method to determine the concentrations of both $\beta-C Y$ and 3-PBA simultaneously in degradable systems. They found a novel $\beta-C Y$ degrading strain, Bacillus licheniformis B-1 isolated from the soil of tea garden, utilized $\beta-C Y$ as growth's substrate. First, they identified the detector wavelength of $\beta-C Y$ and 3-PBA. The baseline was in fact improved at $210.00 \mathrm{~nm}$ and high-resolution peaks received at this wavelength were narrow and symmetric, the wavelength of $210 \mathrm{~nm}$, and the proximity of the maximum wavelengths, was deemed to be provided for the simultaneous determination of both $\beta-C Y$ and 3-PBA. The intra-day's and inter-day's peak areas of $\beta-C Y$ and 3-PBA were compared; recovery also was tested. The limits of detection were 0.06 and $0.13 \mu \mathrm{g} / \mathrm{mL}$ for $\beta-C Y$ and 3-PBA respectively, and the corresponding limits of quantification were 0.21 and $0.34 \mu \mathrm{g} / \mathrm{mL}$ respectively. Spiking recoveries for $\beta-C Y$ varied from $98.38 \%$ to $105.80 \%$, with relative standard deviations (RSDs) varying from $1.49 \%$ to $3.93 \%$. Spiking recoveries for 3-PBA varied from $99.59 \%$ to $101.20 \%$, with RSDs varying from $0.58 \%$ to $3.64 \%$ [113]. Deng et al. studied the kinetic parameters of degradation of 3-PBA by YAT under the effects of different factors, and the results are shown in Table 5 [81]. The results showed that alkaline conditions could increase the 3-PBA's degradable rate, whereas the acidic conditions might increase the stability of 3-PBA and its resistance to chemical and microbial degradation of 3-PBA. Except that, they also discussed the growth's characteristics and the degradable capacity of 3-PBA for Aspergillus niger YAT. The results showed that 3-PBA made some differences in the growth of YAT; it not only prolonged the lag phase of YAT, but also affects its final amount of growth. The strain could degrade all of the 3-PBA $(100 \mathrm{mg} / \mathrm{L})$ in $22 \mathrm{~h}$, which proved that YAT was highly efficient [81]. The two bacteria PBM11 and CDT3 played a role synchronously in the degradation of CY and 3-PBA, which accelerated the degradable rate of $\mathrm{CY}$ and reduced pesticide residues. But, during culturing the CY and strain PBM11 alone, the existence of CY on the growth of strain PBM11 had no obvious effect. Similarly putting degrading bacteria CDT3 and 3-PBA alone, the presence of 3-PBA could produce a certain inhibition on degrading $\mathrm{CY}$ and the degradable rate was negatively correlated with the concentration of 3-PBA. But, when the concentration of 3-PBA was lower than $200 \mathrm{mg} / \mathrm{L}$, the final degradable rate of CDT3 to CY was unchanged after a sufficiently long time. In addition, the study also showed the optimum proportion of strains CDT3 and PBM11 to degrade CY and 3-PBA.

Table 4. Degradation characteristics of the $\beta-\mathrm{CY}$ and 3-PBA-degrading bacteria.

\begin{tabular}{|c|c|c|c|c|}
\hline \multirow{2}{*}{ Strain } & \multirow{2}{*}{$\begin{array}{c}\text { Accession } \\
\text { Number (NCBI) }\end{array}$} & \multirow{2}{*}{ Source } & \multicolumn{2}{|c|}{ Degradation Characteristics (\%) } \\
\hline & & & $\beta-C Y$ & 3-PBA \\
\hline B. licheniformis B-1 & HQ009796 & Tea garden soil & $52.91 \%$ & - \\
\hline Aspergillus oryzae M-4 & JF461319 & Soy sauce koji & $26.01 \%$ & $80.10 \%$ \\
\hline Sphingomonas sp SC-1 & JN857975 & The sludge of pesticide factory wastewater & - & $99.99 \%$ \\
\hline
\end{tabular}

Table 5. Kinetic parameters of degradation of 3-PBA by YAT under the effects of different factors (Taken from Deng et al. 2015).

\begin{tabular}{|c|c|c|c|c|c|}
\hline Factors & & Kinetic Equation & $T_{1 / 2}(h)$ & $K_{d}\left(\mathrm{mg} /(\mathrm{L} \cdot \mathrm{h})^{-1}\right)$ & $\mathbf{R}^{2}$ \\
\hline \multirow{5}{*}{$\mathrm{C}_{0}(\mathrm{mg} / \mathrm{L})$} & 50 & $C_{t}=50.22 e^{-0.123 t}$ & 5.635 & 0.123 & 0.935 \\
\hline & 100 & $C_{t}=101.24 e^{-0.101 t}$ & 6.863 & 0.101 & 0.924 \\
\hline & 150 & $C_{t}=150.51 e^{-0.057 t}$ & 12.160 & 0.057 & 0.957 \\
\hline & 25 & $C_{t}=100.87 e^{-0.062 t}$ & 11.180 & 0.062 & 0.943 \\
\hline & 30 & $C_{t}=101.24 e^{-0.101 t}$ & 6.863 & 0.101 & 0.924 \\
\hline \multirow{2}{*}{ Temperature $\left({ }^{\circ} \mathrm{C}\right)$} & 35 & $C_{t}=100.41 e^{-0.107 t}$ & 6.478 & 0.107 & 0.963 \\
\hline & 6.0 & $C_{t}=100.87 e^{-0.093 t}$ & 7.453 & 0.093 & 0.902 \\
\hline \multirow{2}{*}{$\mathrm{pH}$} & 7.0 & $C_{t}=101.24 \mathrm{e}^{-0.101 \mathrm{t}}$ & 6.863 & 0.101 & 0.924 \\
\hline & 8.0 & $C_{t}=100.97 e^{-0.106 t}$ & 6.539 & 0.106 & 0.970 \\
\hline
\end{tabular}




\section{Conclusions and Outlook}

The microbial degradation studies of pesticides had been greatly developed, and most of the pesticide degrading microbial strains have also been identified, but the actual application of microbial bioremediation was limited, which was often due to its low-degradable efficiency and the environment condition. Mineralization and co-metabolism were the main mechanisms for the further degradation of pesticides and their intermediate products, while the group and molecular structure of pesticide determined its degradation behavior in the microbial environment, chemical structure determined its solubility, in which molecular orientation, spatial structure, chemical functional groups, intermolecular attraction, and repulsion characteristics effecting the ingestion of pesticides by microorganism. The main research directions of microbial degradation of pesticides were: the development of high efficiency pesticide degradation engineering bacteria, the cultivation of mixed bacteria, the immobilization of degrading bacteria, the research of pesticides-degrading fungi, and the quantitative study of pesticide biodegradation model. In recent years, with the development of genetic engineering and molecular biology, on the one hand, researchers began to shift to the construction of efficient engineering bacteria, and used the gene recombination technique. On the other hand, they transformed enzyme gene to construct the vector that could express efficiently the characteristics of degrading pesticide. After that, engineering bacteria could be received. The purpose of that was to improve the expression level of specific proteins or enzymes, so as to improve the efficiency of degradation, which could overcome the problem that some enzymes in the environment could not be stabilized and maintain a high enzyme activity. In short, there was an effective method to eliminate pesticide pollution, which was using microbial agents or fertilizer preparation applied in polluted environment. The difference of pyrethroid degradation in the human body was still not very clear. Although the isolation and screening of degrading bacteria and their degradable effect were better, the research of synergistic degradation target of various degrading bacteria was rarely seen. What was more, a large number of experimental studies could not be applied in practical production. A large number of 3-PBA residues not only caused two pollutions of agricultural products, but also led to pyrethroid pesticides being blocked in biomineralization, which indirectly caused the pesticide residue problems to become more serious and had a threat to food safety, the environment, and human health. The isolation and screening on degradable strain of 3-PBA and the degradable characteristics of strains have been studied currently, but there was no related literature and reports that combined specific methods to study the degradation mechanism of 3PBA being degraded to phenolic compounds. For example, chromatography and mass spectrometry, degradable pathway, catalytic mechanism, enzymatic characteristics, and so on should be emphasized. Although heterologous compounds may be partially or completely decomposed by some microorganisms, they may be resistant to degradation in the environment due to their greater structure, insolubility, and high thermal stability. Therefore, we also need to pay attention to this problem to ensure strain and xenobiotic compounds' degradation products harmless in pollution remediation $[143,144]$.

Author Contributions: D.L. initiated the writing of this review and designed the structure of this manuscript, interpreted results, and drafted the manuscript. Y.H., L.X., and F.L. compiled information and made contribution to the revision of the manuscript. M.X., and X.L. designed the structure of this review, interpreted results, and revised the language. Z.W. gave some valuable advices about the structure of the manuscript.

Funding: This research was funded by the National Natural Science Foundation of China (41807364), the "211 Engineering Double Support Plan (No.03572081)", Sichuan Agricultural University, and the education department of Sichuan Province major project for financial support (No.17ZB0338).

Conflicts of Interest: We declare that no conflict of interest exists in the submission of this manuscript. 


\section{References}

1. Food and Agriculture Organization of the United Nations. Available online: http:/ /www.fao.org/faostat/ en/\#data/QC (accessed on 19 August 2018).

2. Solà, M.; Riudavets, J.; Agustí, N. Detection and Identification of Five Common Internal Grain Insect Pests by Multiplex PCR. Food Control 2018, 84, 246-254. [CrossRef]

3. Pimentel, D.; McNair, S.; Janecka, J.; Wightman, J.; Simmonds, C.; O'connell, C.; Wong, E.; Russel, L.; Zern, J.; Aquino, T.; et al. Economic and Environmental Threats of Alien Plant, Animal, and Microbe Invasions. Agric. Ecosyst. Environ. 2001, 84, 1-20. [CrossRef]

4. Walter, G.H.; Chandrasekaran, S.; Collins, P.J.; Jagadeesan, R.; Mohankumar, S.; Alagusundaram, K.; Ebert, P.R.; Daglish, G.J.; Nayak, M.K.; Mohan, S.; et al. The Grand Challenge of Food Security: General Lessons from A Comprehensive Approach to Protecting Stored Grain from Insect Pests in Australia and India. Indian J. Entomol. 2016, 78, 7-16. [CrossRef]

5. Singh, B.K.; Walker, A. Microbial Degradation of Organophosphorus Compounds. FEMS Microbiol. Rev. 2006, 30, 428-471. [CrossRef] [PubMed]

6. Chen, S.; Sun, D.; Chung, J.S. Treatment of Pesticide Wastewater by Moving-Bed Biofilm Reactor Combined with Fenton-Coagulation Pretreatment. J. Hazard. Mater. 2007, 144, 577-584. [CrossRef] [PubMed]

7. Fenner, K.; Canonica, S.; Wackett, L.P.; Elsner, M. Evaluating Pesticide Degradation in the Environment: Blind Spots and Emerging Opportunities. Science 2013, 341, 752-758. [CrossRef] [PubMed]

8. Mrema, E.J.; Rubino, F.M.; Colosio, C. Obsolete Pesticides-A Threat to Environment, Biodiversity and Human Health. Environ. Secur. Assess. Manag. Obsolete. Pestic. Southeast Eur. 2013, 134, 1-21. [CrossRef]

9. Nayak, S.K.; Dash, B.; Baliyarsingh, B. Microbial Remediation of Persistent Agro-chemicals by Soil Bacteria: An Overview. Microb. Biotechnol. 2018, 275-301. [CrossRef]

10. Abdallah, O.I.; Hanafi, A.; Ghani, S.B.A.; Ghisoni, S.; Lucini, L. Pesticides Contamination in Egyptian Honey Samples. J. Consum. Prot. Food Saf. 2017, 12, 317-327. [CrossRef]

11. Tosi, S.; Costa, C.; Vesco, U.; Quaglia, G.; Guido, G. A 3-Year Survey of Italian Honey Bee-Collected Pollen Reveals Widespread Contamination by Agricultural Pesticides. Sci. Total Environ. 2018, 615, 208-218. [CrossRef] [PubMed]

12. Lehmann, E.; Fargues, M.; Dibié, J.J.N.; Konaté, Y.; de Alencastro, L.F. Assessment of Water Resource Contamination by Pesticides in Vegetable-Producing Areas in Burkina Faso. Environ. Sci. Pollut. 2018, 25, 3681-3694. [CrossRef] [PubMed]

13. Achour, A.; Derouiche, A.; Barhoumi, B.; Kort, B.; Cherif, D.; Bouabdallah, S.; Sakly, M.; Rhouma, K.B.; Touil, S.; Driss, M.R.; et al. Organochlorine Pesticides and Polychlorinated Biphenyls in Human Adipose Tissue from Northern Tunisia: Current Extent of Contamination and Contributions of Socio-Demographic Characteristics and Dietary Habits. Environ. Res. 2017, 156, 635-643. [CrossRef] [PubMed]

14. Audus, L.J. The Biological Detoxication of 2: 4-Dichlorophenoxyacetic Acid in Soil. Plant Soil 1949, 2, 31-36. [CrossRef]

15. Akbar, S.; Sultan, S. Soil Bacteria Showing a Potential of Chlorpyrifos Degradation and Plant Growth Enhancement. Braz. J. Microbiol. 2016, 47, 563-570. [CrossRef] [PubMed]

16. Jabeen, H.; Iqbal, S.; Anwar, S.; Parales, R.E. Optimization of Profenofos Degradation by A Novel Bacterial Consortium PBAC Using Response Surface Methodology. Int. Biodeter. Biodegr. 2015, 100, 89-97. [CrossRef]

17. Ramya, S.L.; Venkatesan, T.; Srinivasa Murthy, K.; Jalali, S.K.; Verghese, A. Detection of Carboxylesterase and Esterase Activity in Culturable Gut Bacterial Flora Isolated from Diamondback Moth, Plutella Xylostella (Linnaeus), From India And Its Possible Role in Indoxacarb Degradation. Braz. J. Microbiol. 2016, 47, 327-336. [CrossRef] [PubMed]

18. Ye, X.; Dong, F.; Lei, X. Microbial Resources and Ecology-Microbial Degradation of Pesticides. Nat. Resour. Conserv. Res. 2018, 1. [CrossRef]

19. Jaiswal, D.K.; Verma, J.P.; Yadav, J. Microbe induced degradation of pesticides in agricultural soils. In Microbe-Induced Degradation of Pesticides; Springer: Cham, Switzerland, 2017; pp. 167-189. [CrossRef]

20. Verma, J.P.; Jaiswal, D.K.; Sagar, R. Pesticide Relevance and Their Microbial Degradation: A-State-of-Art. Rev. Environ. Sci. Technol. 2014, 13, 429-466. [CrossRef]

21. Singh, D.K. Biodegradation and Bioremediation of Pesticide in Soil: Concept, Method and Recent Developments. Indian. J. Microbial. 2008, 48, 35-40. [CrossRef] [PubMed] 
22. Huong, N.L.; Itoh, K.; Suyama, K. 2,4-dichlorophenoxyacetic acid (2,4-D)-and 2,4, 5-trichlorophenoxyacetic acid (2,4,5-T)-degrading bacterial community in soil-water suspension during the enrichment process. Microbes Environ. 2008, 23, 142-148. [CrossRef] [PubMed]

23. Arbeli, Z.; Fuentes, C.L. Accelerated Biodegradation of Pesticides: An Overview of the Phenomenon, its Basis and Possible Solutions; and A Discussion on The Tropical Dimension. J. Crop. Prot. 2007, 26, 1733-1746. [CrossRef]

24. Racke, K.D.; Skidmore, M.; Hamilton, D.J.; Unsworth, J.B.; Miyamoto, J.; Cohen, S.Z. Pesticide Fate in Tropical Soils. Pest. Manag. Sci. 2015, 55, 219-220. [CrossRef]

25. Oliveira, B.R.; Penetra, A.; Cardoso, V.V.; Benoliel, M.J.; Crespo, M.B.; Samson, R.A.; Pereira, V.J. Biodegradation of Pesticides Using Fungi Species Found in The Aquatic Environment. Environ. Sci. Pollut. Res. Int. 2015, 22, 11781-11791. [CrossRef] [PubMed]

26. Soulas, G.; Lagacherie, B. Modelling of Microbial Degradation of Pesticides in Soils. Biol. Fertil. Soils 2001, 33, 551-557. [CrossRef]

27. Liu, M.; Yang, Y.; Xu, S.; Liu, H.; Hou, L.; Ou, D.; Liu, Q.; Cheng, S. HCHs and DDTs in Salt Marsh Plants Scirpus from the Yangtze Estuary and Nearby Coastal Areas, China. Chemosphere 2006, 62, 440-448. [CrossRef] [PubMed]

28. Jin, M.Q.; Zhou, S.S.; Liu, W.P.; Zhang, D.; Lu, X.T. Residues and Potential Health Risks of DDTs and HCHs in Commercial Seafoods from Two Coastal Cities near Yangtze River Estuary. J. Environ. Sci. Health 2015, 50, 163-174. [CrossRef] [PubMed]

29. Hajjar, N.P.; Casida, J.E. Insecticidal Benzoylphenyl Ureas: Structure-Activity Relationships as Chitin Synthesis Inhibitors. Science 1978, 200, 1499-1500. [CrossRef] [PubMed]

30. Beeman, R.W.; Matsumura, F. Chlordimeform: A Pesticide Acting Upon Amine Regulatory Mechanisms. Nature 1973, 242, 273. [CrossRef] [PubMed]

31. Chowdhury, M.A.Z.; Fakhruddin, A.N.M.; Islam, M.N.; Moniruzzaman, M.; Gan, S.H.; Alam, M.K. Detection of The Residues of Nineteen Pesticides in Fresh Vegetable Samples Using Gas Chromatography-Mass Spectrometry. Food Control 2013, 34, 457-465. [CrossRef]

32. Bhandari, G. Mycoremediation: An Eco-friendly Approach for Degradation of Pesticides. In Mycoremediation and Environmental Sustainability; Springer: Cham, Switzerland, 2017; pp. 119-131. [CrossRef]

33. Upadhyay, L.S.; Dutt, A. Microbial Detoxification of Residual Organophosphate Pesticides in Agricultural Practices. In Microbial Biotechnology; Springer: Singapore, 2017; pp. 225-242. [CrossRef]

34. Awumbila, B.; Bokuma, E. Survey of Pesticides Used in the Control of Ectoparasites of Farm Animals in Ghana. Trop. Anim. Health Prod. 1994, 26, 7-12. [CrossRef] [PubMed]

35. Maloney, S.E. Pesticide Degradation. In Fungi in Bioremediation, 3rd ed.; Gadd, G.M., Ed.; the British Mycological Society: New York, NY, USA, 2001; Volume 8, pp. 188-223. ISBN 0-521-78119-1.

36. Liu, B.; Zhou, P.; Liu, X.; Sun, X.; Li, H.; Lin, M. Detection of Pesticides in Fruits by Surface-Enhanced Raman Spectroscopy Coupled with Gold Nanostructures. Food Bioprocess Technol. 2013, 6, 710-718. [CrossRef]

37. Chaussonnerie, S.; Saaidi, P.L.; Ugarte, E.; Barbance, A.; Fossey, A.; Barbe, V.; Gyapay, G.; Brüls, T.; Chevallier, M.; Couturat, L.; et al. Microbial Degradation of a Recalcitrant Pesticide: Chlordecone. Front. Microbiol. 2016, 7, 2025. [CrossRef] [PubMed]

38. Sagar, V.; Singh, D.P. Biodegradation of Lindane Pesticide by Non White-Rots Soil Fungus Fusarium Sp. World J. Microb. Biot. 2011, 27, 1747-1754. [CrossRef]

39. Hai, F.I.; Modin, O.; Yamamoto, K.; Fukushi, K.; Nakajima, F.; Nghiem, L.D. Pesticide Removal by A Mixed Culture of Bacteria and White-Rot Fungi. J. Taiwan Inst. Chem. E 2012, 43, 459-462. [CrossRef]

40. Mohamed, A.K.; Pratt, J.P.; Nelson, F.R. Compatability of Metarhizium Anisopliae Var. Anisopliae with Chemical Pesticides. Mycopathologia 1987, 99, 99-105. [CrossRef] [PubMed]

41. Boncristiani, H.; Underwood, R.; Schwarz, R.; Evans, J.D.; Pettis, J. Direct Effect of Acaricides on Pathogen Loads and Gene Expression Levels in Honey Bees Apis Mellifera. J. Insect Physiol. 2012, 58, 613-620. [CrossRef] [PubMed]

42. Prabha, R.; Singh, D.P.; Verma, M.K. Microbial Interactions and Perspectives for Bioremediation of Pesticides in the Soils. In Plant-Microbe Interactions in Agro-Ecological Perspectives; Springer: Singapore, 2017; pp. 649-671. [CrossRef] 
43. Jiang, J.; Li, S. Microbial Degradation of Chemical Pesticides and Bioremediation of Pesticide-Contaminated Sites in China. In Twenty Years of Research and Development on Soil Pollution and Remediation in China; Springer: Singapore, 2018; pp. 655-670. [CrossRef]

44. Esposito, E.; Paulillo, S.M.; Manfio, G.P. Biodegradation of the Herbicide Diuron in Soil by Indigenous Actinomycetes. Chemosphere 1998, 37, 541-548. [CrossRef]

45. Tang, W. Research Progress of Microbial Degradation of Organophosphorus Pesticides. Prog. Appl. Microbiol. 2018, 1, 29-35.

46. Nour, E.H.; Elsayed, T.R.; Springael, D.; Smalla, K. Comparable Dynamics of Linuron Catabolic Genes and Incp-1 Plasmids in Biopurification Systems Bpss as A Response to Linuron Spiking. Appl. Microbiol. Biot. 2017, 101, 4815-4825. [CrossRef] [PubMed]

47. Ishag, A.E.S.A.; Abdelbagi, A.O.; Hammad, A.M.A.; Elsheikh, E.A.E.; Elsaid, O.E.; Hur, J.H. Biodegradation of Endosulfan and Pendimethalin by Three Strains of Bacteria Isolated from Pesticides-Polluted Soils in The Sudan. Appl. Biol. Chem. 2017, 60, 287-297. [CrossRef]

48. Ngowi, A.V.F.; Mbise, T.J.; Ijani, A.S.M.; London, L.; Ajayi, O.C. Smallholder Vegetable Farmers in Northern Tanzania: Pesticides Use Practices, Perceptions, Cost and Health Effects. Crop Prot. 2007, 26, 1617-1624. [CrossRef] [PubMed]

49. Martins, M.R.; Santos, C.; Pereira, P.; Cruz-Morais, J.; Lima, N. Metalaxyl Degradation by Mucorales Strains Gongronella Sp. and Rhizopus Oryzae. Molecules 2017, 22, 2225. [CrossRef] [PubMed]

50. Johnsen, K.; Jacobsen, C.S.; Torsvik, V.; Sørensen, J. Pesticide Effects on Bacterial Diversity in Agricultural Soils-A Review. Biol. Fert. Soils 2001, 33, 443-453. [CrossRef]

51. Ghaffar, I.; Imtiaz, A.; Hussain, A.; Javid, A.; Jabeen, F.; Akmal, M.; Qazi, J.I. Microbial Production and Industrial Applications of Keratinases: An Overview. Int. Microbiol. 2018, 1-12. [CrossRef]

52. Kafilzadeh, F.; Ebrahimnezhad, M.; Tahery, Y. Isolation and Identification of Endosulfan-Degrading Bacteria and Evaluation of Their Bioremediation in Kor River, Iran. Osong Public Health Res. Perspect. 2015, 6, $39-46$. [CrossRef] [PubMed]

53. Jayabarath, J.; Musfira, S.A.; Giridhar, R.; Arulmurugan, R. Biodegradation of Carbofuran Pesticide by Saline Soil Actinomycetes. Int. J. Biotechnol. Biochem. 2010, 6, 187-193.

54. Elgueta, S.; Santos, C.; Lima, N.; Diez, M.C. Immobilization of The White-Rot Fungus Anthracophyllum Discolor to Degrade the Herbicide Atrazine. AMB Express 2016, 6, 104. [CrossRef] [PubMed]

55. Kabra, A.N.; Ji, M.K.; Choi, J.; Kim, J.R.; Govindwar, S.P.; Jeon, B.H. Toxicity of Atrazine and Its Bioaccumulation and Biodegradation in A Green Microalga, Chlamydomonas Mexicana. Environ. Sci. Pollutr. 2014, 21, 12270-12278. [CrossRef] [PubMed]

56. Briceño, G.; Vergara, K.; Schalchli, H.; Palma, G.; Tortella, G.; Fuentes, M.S.; Diez, M.C. Organophosphorus Pesticide Mixture Removal from Environmental Matrices by A Soil Streptomyces Mixed Culture. Environ. Sci. Pollut. 2017,1-12. [CrossRef] [PubMed]

57. Bending, G.D.; Friloux, M.; Walker, A. Degradation of Contrasting Pesticides by White Rot Fungi and Its Relationship with Ligninolytic Potential. FEMS Microbiol. Lett. 2002, 212, 59-63. [CrossRef] [PubMed]

58. Romero-Aguilar, M.; Tovar-Sánchez, E.; Sánchez-Salinas, E.; Mussali-Galante, P.; Sánchez-Meza, J.C.; Castrejón-Godínez, M.L.; Dantán-González, E.; Trujillo-Vera, M.A.; Ortiz-Hernández, M.L. Penicillium sp. as an Organism that Degrades Endosulfan and Reduces Its Genotoxic Effects. SpringerPlus 2014, 3, 536. [CrossRef] [PubMed]

59. Kullman, S.W.; Matsumura, F. Metabolic Pathways Utilized by Phanerochaete Chrysosporium for Degradation of the Cyclodiene Pesticide Endosulfan. Appl. Environ. Microbiol. 1996, 62, 593-600. [PubMed]

60. Kataoka, R.; Takagi, K.; Sakakibara, F. A New Endosulfan-Degrading Fungus, Mortierella Species, Isolated from A Soil Contaminated with Organochlorine Pesticides. J. Pestic. Sci. 2010, 35, 326-332. [CrossRef]

61. Birolli, W.G.; Alvarenga, N.; Seleghim, M.H.; Porto, A.L. Biodegradation of the Pyrethroid Pesticide Esfenvalerate by Marine-Derived Fungi. Mar. Biotechnol. 2016, 18, 511-520. [CrossRef] [PubMed]

62. Baarschers, W.H.; Heitland, H.S. Biodegradation of Fenitrothion and Fenitrooxon by the Fungus Trichoderma Viride. J. Agric. Food Chem. 1986, 34, 707-709. [CrossRef]

63. Wolfand, J.M.; LeFevre, G.H.; Luthy, R.G. Metabolization and Degradation Kinetics of the Urban-Use Pesticide Fipronil by White Rot Fungus Trametes Versicolor. Environ. Sci. Process. Impacts 2016, 18, 1256-1265. [CrossRef] [PubMed] 
64. Xiao, P.F.; Mori, T.; Kondo, R. Bioconversion of Heptachlor Epoxide by Wood-Decay Fungi and Detection of Metabolites. Adv. Mater. Res. 2012, 518, 29-33. [CrossRef]

65. Day, K.; Kaushik, N.K. The Adsorption of Fenvalerate to Laboratory Glassware and the Alga Chlamydomonas Reinhardii, and Its Effect on Uptake of The Pesticide by Daphnia Galeata Mendotae. Aquat. Toxicol. 1987, 10, 131-142. [CrossRef]

66. Shehata, S.A.; El-Dib, M.A.; Waly, H.A. Effect of Certain Herbicides on the Growth of Freshwater Algae. Water Air Soil Pollut. 1997, 100,1-12. [CrossRef]

67. Zhang, H.; Ma, D.; Qiu, R.; Tang, Y.; Du, C. Non-Thermal Plasma Technology for Organic Contaminated Soil Remediation: A Review. Chem. Eng. J. 2017, 313, 157-170. [CrossRef]

68. Kaur, H.; Kapoor, S.; Kaur, G. Application of Ligninolytic Potentials of a White-Rot Fungus Ganoderma Lucidum for Degradation of Lindane. Environ. Monit. Assess. 2016, 188, 588. [CrossRef] [PubMed]

69. Qu, J.; Xu, Y.; Ai, G.M.; Liu, Y.; Liu, Z.P. Novel Chryseobacterium sp. PYR2 Degrades Various Organochlorine Pesticides OCPs and Achieves Enhancing Removal and Complete Degradation of DDT in Highly Contaminated Soil. J. Environ. Manag. 2015, 161, 350-357. [CrossRef] [PubMed]

70. Chen, S.; Hu, Q.; Hu, M.; Luo, J.; Weng, Q.; Lai, K. Isolation and Characterization of a Fungus Able to Degrade Pyrethroids and 3-Phenoxybenzaldehyde. Bioresour. Technol. 2011, 102, 8110-8116. [CrossRef] [PubMed]

71. De Souza, M.L.; Sadowsky, M.J.; Wackett, L.P. Atrazine Chlorohydrolase from Pseudomonas Sp. Strain ADP: Gene Sequence, Enzyme Purification, and Protein Characterization. J. Bacteriol. 1996, 178, 4894-4900. [CrossRef] [PubMed]

72. Wackett, L.; Sadowsky, M.; Martinez, B.; Shapir, N. Biodegradation of Atrazine and Related S -Triazine Compounds: From Enzymes to Field Studies. Appl. Microbiol. Biotechnol. 2002, 58, 39-45. [CrossRef] [PubMed]

73. Czarnecki, J.; Dziewit, L.; Puzyna, M.; Prochwicz, E.; Tudek, A.; Wibberg, D.; Schlüter, A.; Pühler, A.; Bartosik, D. Lifestyle-Determining Extrachromosomal Replicon pAMV1 and its Contribution to the Carbon Metabolism of the Methylotrophic Bacterium Paracoccus Aminovorans JCM 7685. Environ. Microbiol. 2017, 19, 4536-4550. [CrossRef] [PubMed]

74. Don, R.H.; Pemberton, J.M. Genetic and Physical Map of the 2, 4-Dichlorophenoxyacetic Acid-Degradative Plasmid pJP4. J. Bacteriol. 1985, 161, 466-468. [PubMed]

75. Mai, P.; Jacobsen, O.S.; Aamand, J. Mineralization and Co-Metabolic Degradation of Phenoxyalkanoic Acid Herbicides by a Pure Bacterial Culture Isolated from an Aquifer. Appl. Microbiol. Biotechnol. 2001, 56, 486-490. [CrossRef] [PubMed]

76. Boivin, A.; Amellal, S.; Schiavon, M.; Van Genuchten, M.T. 2, 4-Dichlorophenoxyacetic Acid 2, 4-D Sorption and Degradation Dynamics in Three Agricultural Soils. Environ. Pollut. 2005, 138, 92-99. [CrossRef] [PubMed]

77. Arora, P.K.; Sasikala, C.; Ramana, C.V. Degradation of Chlorinated Nitroaromatic Compounds. Appl. Microbiol. Biotechnol. 2012, 93, 2265-2277. [CrossRef] [PubMed]

78. Chen, S.H.; Hu, M.Y.; Liu, J.J.; Zhong, G.H.; Yang, L.; Rizwan-ul-Haq, M.; Han, H. Biodegradation of Beta-cypermethrin and 3-Phenoxybenzoic Acid by a Novel Ochrobactrum lupini DG-S-01. J. Hazard. Mater. 2011, 187, 433-440. [CrossRef] [PubMed]

79. Zhang, C.; Jia, L.; Wang, S.H.; Qu, J.; Li, K.; Xu, L.L.; Shi, Y.H.; Han, Y.C. Biodegradation of Beta-Cypermethrin by Two Serratia Spp. with Different Cell Surface Hydrophobicity. Bioresour. Technol. 2010, 101, 3423-3429. [CrossRef] [PubMed]

80. García-Reyes, J.F.; Molina-Díaz, A.; Fernández-Alba, A.R. Identification of Pesticide Transformation Products in Food by Liquid Chromatography/Time-of-Flight Mass Spectrometry via "Fragmentation-Degradation" Relationships. Anal. Chem. 2007, 79, 307-321. [CrossRef] [PubMed]

81. Deng, W.Q.; Lin, D.R.; Yao, K.; Yuan, H.Y.; Wang, Z.L.; Li, J.L.; Zou, L.K.; Han, X.F.; Zhou, K.; He, L.; et al. Characterization of a Novel $\beta$-cypermethrin-degrading Aspergillus Niger, YAT Strain and the Biochemical Degradation Pathway of $\beta$-cypermethrin. Appl. Microbiol. Biotechnol. 2015, 99, 8187-8198. [CrossRef] [PubMed]

82. Hugo, H.J.; Mouton, C.; Malan, A.P. Accelerated Microbial Degradation of Nematicides in Vineyard and Orchard Soils. S. Afr. J. Enol. Vitic. 2014, 35, 157-167. [CrossRef] 
83. Hussain, S.; Siddique, T.; Saleem, M.; Arshad, M.; Khalid, A. Chapter 5 Impact of Pesticides on Soil Microbial Diversity, Enzymes, and Biochemical Reactions. Adv. Agron. 2009, 102, 159-200. [CrossRef]

84. Zhang, Z.; Zheng, P.; Li, W.; Wang, R.; Ghulam, A. Effect of Organic Toxicants on the Activity of Denitrifying Granular Sludge. Environ. Technol. 2015, 36, 699-705. [CrossRef] [PubMed]

85. Tsai, Y.S.; Huang, J.L.; Lin, C.S. Application of Host Cell Reactivation in Evaluating the Effects of Anticancer Drugs and Environmental Toxicants on Cellular DNA Repair Activity in Head and Neck Cancer. Sel. Top. DNA Repair 2011, 465-482. [CrossRef]

86. Baxter, J.; Cummings, S.P. The Application of the Herbicide Bromoxynil to a Model Soil-Derived Bacterial Community: Impact on Degradation and Community Structure. Lett. Appl. Microbiol. 2006, 43, 659-665. [CrossRef] [PubMed]

87. Chaw, D.; Stoklas, U. Cocomposting of Cattle Manure and Hydrocarbon Contaminated Flare Pit Soil. Compost. Sci. Util. 2013, 9, 322-335. [CrossRef]

88. Chrzanowski, Ł.; Dziadas, M.; Ławniczak, Ł.; Cyplik, P.; Białas, W.; Szulc, A.; Lisiecki, P.; Jeleń, H. Biodegradation of Rhamnolipids in Liquid Cultures: Effect of Biosurfactant Dissipation on Diesel Fuel/B20 Blend Biodegradation Efficiency and Bacterial Community Composition. J. Bioresour. Technol. 2012, 111, 328-335. [CrossRef] [PubMed]

89. Mahro, B.; Müller, R.; Kasche, V. Bioavailability-The Key Factor of Soil Bioremediation. Treat. Contam. Soil 2012, 181-195. [CrossRef]

90. Luan, T.G.; Keith, S.H.; Zhong, Y.; Zhou, H.W.; Lan, C.Y.; Tam, N.F. Study of Metabolites From the Degradation Of Polycyclic Aromatic Hydrocarbons Pahs by Bacterial Consortium Enriched from Mangrove Sediments. Chemosphere 2006, 65, 2289-2296. [CrossRef] [PubMed]

91. Sartoros, C.; Yerushalmi, L.; Béron, P.; Guiot, S.R. Effects of Surfactant and Temperature on Biotransformation Kinetics of Anthracene and Pyrene. Chemosphere 2015, 61, 1042-1050. [CrossRef] [PubMed]

92. De Pádua Ferreira, R.; Sakata, S.K.; Dutra, F.; Di Vitta, P.; Taddei, M.; Bellini, M.; Marumo, J. Treatment of Radioactive Liquid Organic Waste Using Bacteria Community. J. Radioanal. Nucl. Chem. 2012, 292, 811-817. [CrossRef]

93. Munawar, A. Chemical Characteristics of organic wastes and their potential use for Acid Mine Drainage Remediation. Jurnal Natur Indonesia 2010, 12, 167-172.

94. Bhattacharya, J.; Islam, M.; Cheong, Y.W. Microbial Growth and Action: Implications for Passive Bioremediation of Acid Mine Drainage. J. Mine Water. Environ. 2006, 25, 233-240. [CrossRef]

95. Nakajima, T.; Shigeno, Y. Polyester Plastic-Degrading Microorganism, Polyester Plastic-Degrading Enzyme and Polynucleotide Encoding the Enzyme. EP 1849859B1, 21 January 2014.

96. Acevedo, F.; Pizzul, L.; del Pilar Castillo, M.; Cuevas, R.; Diez, M.C. Degradation of Polycyclic Aromatic Hydrocarbons by the Chilean White-Rot Fungus Anthracophyllum Discolor. J. Hazard. Mater. 2011, 185, 212-219. [CrossRef] [PubMed]

97. Yuan, S.Y.; Chang, S.W.; Chang, B.V. Biodegradation of Polycyclic Aromatic Hydrocarbons in Sludge. Bull. Environ. Contam. Toxicol. 2003, 71, 0625-0632. [CrossRef]

98. Arbeli, Z.; Fuentes, C.L. Microbial Degradation of Pesticides in Tropical Soils. Soil Biol. Agric. Trop. 2010, 21, 251-274. [CrossRef]

99. Zhu, M.; Mccully, L.M.; Silby, M.W.; Charles-Ogan, T.I.; Huang, J.; Brigham, C.J. Draft Genome Sequence of Ralstonia sp. MD27, a Poly3-Hydroxybutyrate-Degrading Bacterium, Isolated from Compost. Genome. Announcements 2015, 3, e01170-15. [CrossRef] [PubMed]

100. Brack, C.; Mikolasch, A.; Schlueter, R.; Otto, A.; Becher, D.; Wegner, U.; Albrecht, D.; Albrecht, K.; Schauer, F. Antibacterial Metabolites and Bacteriolytic Enzymes Produced by Bacillus pumilus during Bacteriolysis of Arthrobacter citreus. Marie Biotechnol. 2015, 17, 290-304. [CrossRef] [PubMed]

101. Gupta, S.; Pathak, B.; Fulekar, M.H. 2015 Molecular Approaches for Biodegradation of Polycyclic Aromatic Hydrocarbon Compounds: A Review. Rev. Environ. Sci. Bio/Technol. 2015, 14, 241-269. [CrossRef]

102. Kim, T.J.; Lee, E.Y.; Kim, Y.J.; Cho, K.S.; Ryu, H.W. Degradation of Polyaromatic Hydrocarbons by Burkholderia Cepacia, 2A-12. World J. Microbiol. Biotechnol. 2003, 19, 411-417. [CrossRef]

103. Singh, B.; Kaur, J.; Singh, K. Microbial Degradation of an Organophosphate Pesticide, Malathion. Crit. Rev. Microbiol. 2014, 40, 146-154. [CrossRef] [PubMed] 
104. Kumar, A.; Trefault, N.; Olaniran, A.O. Microbial Degradation of 2, 4-Dichlorophenoxyacetic Acid: Insight into the Enzymes and Catabolic Genes Involved, their Regulation and Biotechnological Implications. Crit. Rev. Microbiol. 2016, 42, 194-208. [CrossRef] [PubMed]

105. Singh, B.; Singh, K. Microbial Degradation of Herbicides. Crit. Rev. Microbiol. 2016, 42, 245-261. [CrossRef] [PubMed]

106. Chibata, I.; Tosa, T. Immobilized Microbial Cells and their Applications. Trends Biochem. Sci. 1980, 5, 88-90. [CrossRef]

107. Heitkamp, M.A.; Camel, V.; Reuter, T.J.; Adams, W.J. Biodegradation of P-Nitrophenol in an Aqueous Waste Stream by Immobilized Bacteria. Appl. Environ. Microbiol. 1990, 56, 2967-2973. [PubMed]

108. Linko, P.; Linko, Y.Y.; Kennedy, J.F. Industrial Applications of Immobilized Cells. Crit. Rev. Biotechnol. 1983, 1, 289-338. [CrossRef]

109. Smith, G.P. Filamentous Fusion Phage: Novel Expression Vectors that Display Cloned Antigens on the Virion Surface. Science 1985, 228, 1315-1317. [CrossRef] [PubMed]

110. Freudl, R.; MacIntyre, S.; Degen, M.; Henning, U. Cell Surface Exposure of the Outer Membrane Protein OmpA of Escherichia Coli K-12. J. Mol. Biol. 1986, 188, 491-494. [CrossRef]

111. Buvaneswari, G.; Thenmozhi, R.; Nagasathya, A.; Thajuddin, N.; Kumar, P. GC-MS and molecular analyses of Monocrotophos Biodegradation by Selected Bacterial Isolates. Afr. J. Microbiol. Res. 2018, 12, 52-61. [CrossRef]

112. Parte, S.G.; Mohekar, A.D.; Kharat, A.S. Microbial Degradation of Pesticide: A Review. Afr. J. Microbiol. Res. 2017, 11, 992-1012. [CrossRef]

113. Li, J.L.; Lin, D.R.; Ji, R.; Yao, K.; Deng, W.Q.; Yuan, H.Y.; Wu, Q.; Jia, Q.S.; Luo, P.W.; Zhou, K.; et al. Simultaneous Determination of $\beta$-Cypermethrin and Its Metabolite 3-Phenoxybenzoic Acid in Microbial Degradation Systems by HPLC-UV. J. Chromatogr. Sci. 2016, 54, 1584-1592. [CrossRef] [PubMed]

114. Ma, Y.; Wang, L.; Shao, Z. Pseudomonas, the Dominant Polycyclic Aromatic Hydrocarbon-Degrading Bacteria Isolated from Antarctic Soils and the Role of Large Plasmids in Horizontal Gene Transfer. Environ. Microbiol. 2006, 8, 455-465. [CrossRef] [PubMed]

115. Kang, B.K.; Hyunhwan, J.; Kisun, K. Effect of slurry composted and biofiltered solution as an organic fertilizer on the growth of zoysiagrass. J. Hortic. Environ. Biotechnol. 2010, 516, 507-512.

116. Haruta, S.; Cui, Z.; Huang, Z.; Li, M.; Ishii, M.; Igarashi, Y. Construction of a Stable Microbial community with High Cellulose-Degradation Ability. Appl. Microbiol. Biotechnol. 2002, 59, 529-534. [CrossRef] [PubMed]

117. Pérez, J.J.; Williams, M.K.; Weerasekera, G.; Smith, K.; Whyatt, R.M.; Needham, L.L.; Barr, D.B. Measurement of Pyrethroid, Organophosphorus, and Carbamate Insecticides in Human Plasma Using Isotope Dilution Gas Chromatography-High Resolution Mass Spectrometry. J. Chromatogr. B 2010, 878, 2554-2562. [CrossRef]

118. Sinha, C.; Agrawal, A.K.; Islam, F.; Seth, K.; Chaturvedi, R.K.; Shukla, S.; Seth, P.K. Mosquito Repellent Pyrethroid-Based Induced Dysfunction of Blood-Brain Barrier Permeability in Developing Brain. Int. J. Dev. Neurosci. 2004, 22, 31-37. [CrossRef] [PubMed]

119. Kasat, K.; Go, V.; Pogo, B.G.T. Effects of Pyrethroid Insecticides and Estrogen on WNT10B Proto-Oncogene Expression. Environ. Int. 2002, 28, 429-432. [CrossRef]

120. Benli, A.C.K. Investigation of Acute Toxicity of Cyfluthrin on Tilapia Fry (Oreochromis Niloticus L. 1758). Environ. Toxicol. Pharmacol. 2005, 20, 279-282. [CrossRef] [PubMed]

121. Roberts, T.R.; Standen, M.E. Degradation of the Pyrethroid Cypermethrin NRDC $149 \pm$ - $\alpha$-cyano-3-phenoxybenzyl \pm -cis, trans-3-2, 2-dichlorovinyl-2, 2-dimethylcyclopropanecarboxylate and the Respective cis-NRDC 160 and trans-NRDC 159 Isomers in Soils. Pestic. Sci. 1977, 8, 305-319. [CrossRef]

122. Zhang, L.; Gao, X.; Liang, P. Beta-cypermethrin Resistance Associated with High Carboxylesterase Activities in a Strain of House Fly, Musca Domestica (Diptera: Muscidae). Pestic. Biochem. Physiol. 2007, 89, 65-72. [CrossRef]

123. Das, B.K.; Mukherjee, S.C. Toxicity of Cypermethrin in Labeo rohita fingerlings: Biochemical, Enzymatic And Haematological Consequences. Comp. Biochem. Physiol. Part. C Toxicol. Pharmacol. 2003, 134, 109-121. [CrossRef]

124. Tyler, C.R.; Beresford, N.; vander Woning, M.; Sumpter, J.P.; Tchorpe, K. Metabolism and Environmental Degradation of Pyrethroid Insecticides Produce Compounds with Endocrine Activities. Environ. Toxicol. Chem. 2000, 19, 801-809. [CrossRef] 
125. Grant, R.G.; Betts, W.B. Mineraland Carbon Usage of two Synthetic Pyrethroid Degrading Bacterial Isolates. J. Appl. Microbiol. 2004, 97, 656-662. [CrossRef] [PubMed]

126. Kaur, P.; Sharma, A.; Parihar, L. In Vitro Study of Mycoremediation of Cypermethrin-contaminated Soils in Different Regions of Punjab. Ann. Microbiol. 2015, 65, 1949-1959. [CrossRef]

127. Xiao, Y.; Chen, S.; Gao, Y.; Hu, W.; Hu, M.; Zhong, G. Isolation of a Novel Beta-Cypermethrin Degrading Strain Bacillus Subtilis BSF01 and its Biodegradation Pathway. Appl. Microbiol. Biotechnol. 2015, 99, 2849-2859. [CrossRef] [PubMed]

128. Chen, S.H.; Chang, C.Q.; Deng, Y.Y.; An, S.W.; Dong, Y.H.; Zhou, J.N.; Hu, M.Y.; Zhong, G.H.; Zhang, L.H. Fenpropathrin Biodegradation Pathway in Bacillus sp. DG-02 and its Potential for Bioremediation of Pyrethroid-Contaminated Soils. J. Agric. Food. Chem. 2014, 62, 2147-2157. [CrossRef] [PubMed]

129. Tallur, P.N.; Megadi, V.B.; Ninnekar, H.Z. Biodegradation of Cypermethrin by Micrococcus sp. Strain CPN 1. Biodegradation 2008, 19, 77-82. [CrossRef] [PubMed]

130. Topp, E.; Akhtar, M.H. Identification and Characterization of a Pseudomonas Strain Capable of Metabolizing Phenoxybenzoates. Appl. Environ. Microbiol. 1991, 57, 1294. [PubMed]

131. Saikia, N.; Das, S.K.; Patel, B.K.C.; Niwas, R.; Singh, A.; Gopal, M. Biodegradation of Beta-Cyfluthrin by Pseudomonas Stutzeri Strain S1. Biodegradation 2005, 16, 581-589. [CrossRef] [PubMed]

132. Guo, P.; Wang, B.Z.; Hang, B.J.; Li, L.; Ali, S.W.; He, J.; Li, S. Pyrethroid-degrading Sphingobium sp. JZ-2 and the Purification and Characterization of a Novel Pyrethroid Hydrolase. Int. Biodeterior. Biodegrad. 2009, 63, 1107-1112. [CrossRef]

133. Deng, W.Q.; Liu, S.L.; Yao, K. Microbial degradation of 3-phenoxybenzoic acid-A review. Acta Microbiol. Sin. 2015, 559, 1081-1088.

134. Hoellinger, H.; Pichat, L. Synthese des Metabolites de L'Insecticide Deltamethrine: Acides Phenoxy-3 Benzoiques (carboxyle 14C), Alcools Phenoxy-3 Benzyiques hydroxyméthyle 14C. J. Label. Compd. Radiopharm. 1985, 22, 755-760. [CrossRef]

135. Ding, Y.; White, C.A.; Muralidhara, S.; Bruckner, J.V.; Bartlett, M.G. Determination of Deltamethrin and its Metabolite 3-phenoxybenzoic acid in male rat plasma by High-Performance Liquid Chromatography. J. Chromatogr. B 2004, 810, 221-227. [CrossRef]

136. Ji, G.X.; Xia, Y.K.; Gu, A.H.; Shi, X.G.; Long, Y.; Song, L.; Wang, S.L.; Wang, X.R. Effects of Non-Occupational Environmental Exposure to Pyrethroids on Semen Quality and Sperm DNA Integrity in Chinese Men. Reprod. Toxicol. 2011, 31, 171-176. [CrossRef] [PubMed]

137. Han, Y.; Xia, Y.K.; Han, J.Y.; Zhou, J.P.; Wang, S.L.; Zhu, P.F.; Zhao, R.C.; Jin, N.Z.; Song, N.; Wang, X.R. The Relationship of 3-PBA Pyrethroids Metabolite and Male Reproductive Hormones among Non-Occupational Exposure Males. Chemosphere 2008, 72, 785-790. [CrossRef] [PubMed]

138. Jin, M.Q.; Li, L.; Xu, C.; Wen, Y.Z.; Zhao, M.R. Estrogenic Activities of two Synthetic Pyrethroids and their Metabolites. J. Environ. Sci. 2010, 22, 290-296. [CrossRef]

139. Vidal, J.L.M.; Plaza-Bolanos, P.; Romero-González, R.; Frenich, A.G. Determination of Pesticide Transformation Products: A Review of Extraction and Detection Methods. J. Chromatogr. A 2009, 1216, 6767-6788. [CrossRef] [PubMed]

140. Xie, W.J.; Zhou, J.M.; Wang, H.Y.; Chen, X.Q. Effect of Nitrogen on the Degradation of Cypermethrin and its Metabolite 3-phenoxybenzoic Acid in Soil. Pedosphere 2008, 18, 638-644. [CrossRef]

141. Sun, H.; Chen, W.; Xu, X.L.; Ding, Z.; Chen, X.D.; Wang, X.R. Pyrethroid and Their Metabolite, 3-Phenoxybenzoic Acid Showed Similar Antiestrogenic Activity in Human and Rat Estrogen Receptor A-Mediated Reporter Gene Assays. Environ. Toxicol. Pharmacol. 2014, 37, 371-377. [CrossRef] [PubMed]

142. Kumar, M.; Leon, V.; Materano, A.D.S.; Ilzins, O.A. Enhancement of Oil Degradation by Co-Culture of Hydrocarbon Degrading and Biosurfactant Producing Bacteria. Pol. J. Microbiol. 2006, 55, 139-146. [PubMed] 
143. Godheja, J.; Shekhar, S.K.; Siddiqui, S.A.; Modi, D.R. Xenobiotic Compounds Present in Soil and Water: A Review on Remediation Strategies. J. Environ. Anal. Toxicol. 2016, 6, 392. [CrossRef]

144. Narwal, S.K.; Gupta, R. Biodegradation of xenobiotic compounds: An Overview. In Handbook of Research on Inventive Bioremediation Techniques, 1st ed.; University of Kalyani Press: West Bengal, India, 2017; pp. 186-212. ISBN 978-152-252-325-3.

Sample Availability: Samples of all compounds are not available from the authors.

(C) 2018 by the authors. Licensee MDPI, Basel, Switzerland. This article is an open access article distributed under the terms and conditions of the Creative Commons Attribution (CC BY) license (http://creativecommons.org/licenses/by/4.0/). 